\title{
AZ ÁGAZATI GAZDASÁGSZERKEZET SZEREPE A REGIONÁLIS DIFFERENCIÁLÓDÁSBAN MAGYARORSZÁGON ${ }^{1}$
}

(The Role of Sectoral Differentiation in Spatial Development)

\section{KISS JÁNOS}

A területi fejlettség és elmaradottság alapvetően nem véletlenszerüen felbukkanó egyedi tényezök, hanem különféle (társadalmi-gazdasági jellegü) strukturális hatások eredménye, így érdemi befolyásolásuk - azaz a teruletfejlesztés - magától értetödően csak strukturális eszközökkel lehetséges. Mivel az 1990-es években a magyarországi területi fejlỏdés föszereplöjévé egyértelmüen a gazdaság vált (Enyedi 1997), ennek különböző strukturális dimenziókban megnyilvánuló területi különbségei kitüntetett figyelmet kell, hogy kapjanak a hazai területfejlesztési stratégia kialakítása során is.

A magyar gazdaságban a rendszerváltás óta végbement tulajdoni, üzemszervezeti stb. változásokhoz képest egyelöre kevés figyelmet kap a szintén jelentősen megváltozott ágazati szerkezet elemzése, holott a területfejlesztés gyakorlatának világszerte egyik gyakran alkalmazott elemét képezi meghatározott gazdasági ágazatok fejlesztése (Nemes Nagy 1987). A '70-es évekig hazánkban és az európai országok többségében is az iparfejlesztésnek volt meghatározó szerepe, míg napjainkban a neoliberális államok inkább a szolgáltatásokat, illetve az információgazdaságot helyezik elötérbe területfejlesztési stratégiájukban (Enyedi 1997). Számunkra is fontos kérdés, hogy van-e kimutatható összefüggés a magyar gazdaság ágazati szerkezetének regionális különbségei és a területi fejlettségfejlödés között, másként megfogalmazva: miféle ágazati tényezöi vannak egyes térségek dinamikájának és mások lemaradásának napjaink Magyarországán?

Az erre irányuló elemzést makroszinten, a három fö nemzetgazdasági ág országosan általánositható sajátosságainak megfogalmazására törekedve végeztük. A három ágazat közül a - nemzetgazdasági súlyát tekintve ma már egyaránt a szolgáltatások mögé szoruló - mezôgazdaság és ipar kiemelése révén pedig arra kerestük a választ, hogy egyszerúen adaptálhatók-e a hazai viszonyokra az Európai Unió regionális politikájának jelenleg elsösorban a tercier szférát kiemelö ágazati prioritásai vagy egyes régiókban ma is lehetséges az agrárgazdaságra, illetve az iparra alapozni a ierületi fejlỏdés sikerét?

A kérdések megválaszolásához alapvetö jelentöségủ a vizsgálatban szereplö területi szintek egyértelmü rögzitése: nyilvánvaló ugyanis, hogy minél kisebb egységeket vizsgálunk, annál több múlik az egyes ágazatokat képviselö vállalkozások speciális helyi jellegzetességein, annál több a kivétel. $A z$ ágazati szerkezet és a regionális fejlôdés kapcsolata meggyôzzödésünk szerint a kistérségek szintjéig értelmezhetô. A számitásainkban szereplő országon belüli teruleti egységek azonban Magyarország esetében általában a megyék voltak, mert ezekröl ma már rendelkezésre állnak friss és nemzetközileg is összehasonlítható gazdaságszerkezeti 
Az ágazati gazdaságszerkezet szerepe a regionális differenciálódásban Magyarországon.

Tér és Társadalom, 12. 1998. 1-2. 138-162. p.

TÉT 1998 - 1-2

Gyors témykép

139

adatok, ugyanakkor ez az aggregáltság meggyöződésünk szerint még nem fedi el az ország kủlönböző térségeinek legfontosabb gazdaságfejlődési sajátosságait, $\mathrm{s}$ lehetőséget ad az országon belưli ősszehasonlításra is.

A "dinamika" fogalma alatt a továbbiakban elsósorban a gazdaság fejlődéséról értekezunk. Ennek oka egyrészt a gazdaság már említett meghatározó szerepe a területi fejlődésben, másrészt a gazdasági folyamatok viszonylag jó mérhetősége. Praktikus okokból a korábbi időszakok fejlödésének hatásait osszegző, statikus jellegủ gazdasági fejlettségi mutatóknak a jelenlegi ágazati szerkezettel való összefuggéseit is relevánsnak tekintettuk, feltételezve, hogy ezek területi eltérései jól megfeleltethetôk a rendszerváltás óta eltelt rővid időszak dinamikakullönbségeknek is. E helyen is fontos leszögezni azonban, hogy a térségi dinamika többdimenziós fogalom, amelynek a gazdasági fejlödés, a régióban termelt jövedelmek növekedése csak az egyik - igaz, nélkülözhetetlen - tényezöje. A "sikeres régió"-vá váláshoz egyéb tényezớk (pl. az értéknövekmény helyben maradása, széles társadalmi rétegekben való elterjedése, a foglalkoztatási helyzet javulása, a környezetet terhelö "negatív externáliák" csökkentése stb.) is szükségesek (Enyedi 1997).

A felhasznált módszerek zöme az értéktermelés és a foglalkoztatottság ágazati megoszlása, illetve egyes jövedelem-típusú változók (leggyakrabban az egy före jutó GDP) közőtti ősszefuggések kimutatására irányult. Ezek az adatok viszonylag jól ơsszehasonlíthatók, emellett a területi külơnbségek mérésére szolgáló, tơbb változóból képzett "komplex" mutatókkal is szoros kapcsolatban vannak (Nemes Nagy 1987). A részletesebb (al)ágazati bontás mellözése és a relatíve kevés mutató alkalmazása lehetövé tette az EU-régiókkal való összevetést, az analóg és az eltérö(nek látszó) fejlödési sajátosságok kimutatását. Ennek segítségével kísérelünk meg elörejelzést adni arra vonatkozóan is, hogy az általunk feltárt trendek tartósak lesznek-e, avagy csak átmeneti jelenségei az új magyarországi gazdasági tér formálódásának; valamint, hogy a jelenleg eredményesnek mutatkozó regionális gazdaságfejlödési modellek hosszabb távon is sikeresek lehetnek-e.

A viszonylag szük alapadatbázist - a kapcsolatok minél szélesebb körének feltárása céljából - változatos matematikai apparátussal kíséreltuk meg feldolgozni. $\mathrm{Az}$ egyszerủ adattáblák, viszonyszámok, indexek képzésén túl (egyes ágazati jellemzök terúleti koncentrációjának mérésére, valamint a jơvedelmi mutatókkal való kapcsolatok kimutatására) néhány bonyolultabb, vagy ritkábban használatos módszert is alkalmaztunk.

A kutatást számos objektív módszertani probléma nehezítettc. Ezek kểzuli a legfontosabb a részletes területi bontású, és időbeli-térbeni összehasonlításokra is lehetőséget adó ágazati gazdasági adatok szükőssége, az 1994 elötti időszakra hiányzó megyei GDP-számitás, illetve az, hogy a területi GDP-értékek maguk is számos becsléssel megállapitott elemet tartalmaznak. Elméleti szempontból is figyelmet érdemlö probléma, hogy a jövedelmek jelentős része nem termelése helyén kerül felhasználásra, $s$ így a keletkezés helyéhez rendelt GDP-értékek nem tükrözik pontosan a területi egyenlö́tlenségeket. Itt kell rámutatni arra is, hogy az egyes vállalatokat a statisztika fỏtevékenységulk jellege szerint sorolja ágazatokba, holott pl. az ipari cégek egy része tơbb termelő szolgáltatást "internalizál" saját szervezetén belül (Raffay 1997). ${ }^{2}$ Végúl: jelentös területi statisztikai probléma, hogy míg a termelési értéket a munkahely megyéje alapján veszi számba a Központi 
Statisztikai Hivatal, addig a foglalkoztatottakat lakóhelyük megyéje szerint csoportosítja. Ez a különbség - amely a megyehatáron átlépỏ ingázás esetében okozhat torzulásokat a számításokban - a budapesti agglomeráció esetében a legkomolyabb mértékü: a beingázók által eloállított érték Budapest egy före jutó GDP-jét növeli, mig Pest megyéét csökkenti. (A problémát kiküszöbölendö a két teruletet "Központi régió" néven összevonva is elvégeztük a számítások többségét.) A korábbi nemzetközi és hazai tapasztalatok alapján azonban biztosan állitható és a különbözó módszerekkel végzett elemzések egybevágó eredményei is arra utalnak -, hogy a felsorolt és az itt nem emlitett egyéb nehézségek nem teszik lehetetlenné az alapösszefüggések feltárását az ágazati szerkezet és a területi fejlödés kapcsolatainak vonatkozásában sem.

\section{Regionális különbségek a gazdasági szerkezet-átalakulás folyamataiban}

A fejlett országokban a gazdasági növekedés megindulása vagy felgyorsulása az ipari forradalom kezdetétöl az 1970-es évek elejéig egyértelmüen az iparosodáshoz kötỏdött. Az indusztrializáció csúcspontját megelőzỏ évtized - a nyugat-európai országok zömében az 50-es, Magyarországon a 60-as évek - az ágazati szerkezet és a jövedelmek legnagyobb területi egyenlötlenségeinek időszaka volt. (Nemes Nagy 1987). Ekkor volt a legszorosabb összefüggés a regionális gazdaságok ágazati szerkezete és fejlettségük-fejlödésük között, ekkor léteztek a legtipikusabban elkülönullö "ipari", illetve "agrár" körzetek: elöbbiekre értelemszerúen a dinamika, utóbbiakra a hanyatlás vagy stagnálás volt jellemzö.

Az 1970-es évek elején a nyugat-európai országokban válság, majd gazdasági ciklusváltás következett be. A kưlönbözö regionális szinteken is általánosan bekövetkezett tercierizálódás a szolgáltatások gazdasági súlyának növekedése, illetve a foglalkozási átrétegzódés. Ezzel párhuzamosan a termelés földrajzi dekoncentrációja ment végbe: a korábbi egyoldalú ágazati "gazdasági körzetek átalakultak, s részben beszállítói hálózatokkal váltódtak fel" (Enyedi 1996). Mindezek következtében felgyorsult a regionális ágazati szerkezetek nivellálódása és a területi jövedelmi egyenlötlenségek csökkenése.

$\mathrm{Az}$ iparon belül szerkezeti átalakulás következett be: a nyersanyagigényes ágazatok zöme visszaszorult, míg néhány új, a telephelyválasztás hagyományos szempontjaira kevésbé érzékeny "high-tech" iparág dínamikus fejlödésnek indult. Csak kevés korábbi ipari térség bizonyult alkalmasnak - helyzeti elönyei, fejlett infrastruktúrája, illetve iskolázottabb lakossága bázisán - az iparon beluuli váltásra, vagy a tercierizálódás által kínált lehetőségek megragadására (Raffay 1997): az új dinamikus régiók zöme korábbi rurális zónákból keruilt ki (Enyedi 1996).

Az 1990-es évek elejére a fejlett európai országokban - a három fóagazat szintjén legalábbis - erőteljesen lelassultak a gazdaság ágazati szerkezetének átalakulási folyamatai, és a regionális fejlettségi különbségek kiegyenlitödése is minimális sebességul. Az ipar részaránya stabilizálódni látszik, méghozzá országcsoportonként némiképp eltérö szinten. A - napjainkra az EU legfejlettebb régióinak nagyobb részét tömörítö- közép-európai térségben (Németország, ÉszakOlaszország, Ausztria) az ipar foglalkoztatási részesedése a nagyvárosi régiók 
Az ágazati gazdaságszerkezet szerepe a regionális differenciálódásban Magyarországon. Tér és Társadalom, 12. 1998. 1-2. 138-162. p.

kivételével mindenütt meghaladja a 30, a GDP-t tekintve nemritkán a $40 \%$-ot is. Az egykori "atlanti centrum" országaiban és a skandináv államokban viszont ezek az értékek zömmel $30 \%$ alatt maradnak. A szegényebb EU-országok egy részében (föleg portugál és spanyol régiókban) az ipari jelleg erỏsebb, a dél-olasz és görỏg térségekben viszont a mezőgazdaság és a tercier szektor aránya jelentősebb.

Mindeközben a mezógazdaság térvesztése évtizedek óta folyamatos. Aránya a GDP-böl mára a fejlett országokban mindenütt $10 \%$ alá esett, az EU átlagában az 1973-1992 közötti idöszakban 5\%-ról kb. 2,5\%-ra. Az agrárszektor nagy gazdasági súlya a regionális elmaradottság egyik legáltalánosabban elfogadott indikátora. Ennek legföbb oka az, hogy a három fö ágazat közül egyértelmủen $a$ mezögazdaságban a legalacsonyabb az élömunka termelékenysége $e^{3}$ és a jövedelemszínvonal is. Ezt bizonyitja, hogy a 15 jelenlegi EU-tagállamban 1992-ben a hozzáadott értékböl csupán feleakkora volt az agrárágazat részesedése, mint az aktív keresőkből, s igaz ez az összefüggés a regionális egységek túlnyomó többségére is.

A gazdasági szerkezetátalakulás ágazati folyamatait a szocialista országok közül Magyarország követte a leggyorsabban (1. táblázat).

\section{TÁBLÁZAT}

Az aktív kereső́k megoszlása a fö nemzetgazdasági ágak között 1960-1996, (\%)

(Sectoral Division of Labour the Labour Market 1960-1996, \%)

\begin{tabular}{|l|c|c|c|c|c|c|c|c|c|}
\hline & \multicolumn{3}{|c|}{1960} & \multicolumn{3}{c|}{1970} & \multicolumn{3}{c|}{1980} \\
\hline & Ország & Bp. & Megyék & Ország & Bp. & Megyék & Ország & Bp. & Megyék \\
\hline Mezógazdaság & 38,5 & 1,4 & 48,1 & 24,7 & 2,1 & 31,1 & 18,9 & 3,9 & 22,7 \\
\hline Ipar & 33,0 & 54,5 & 27,4 & 43,8 & 54,6 & 40,7 & 42,1 & 45,0 & 41,4 \\
\hline Tercier szektor & 28,5 & 44,1 & 24,5 & 31,5 & 43,3 & 28,2 & 39,0 & 51,1 & 35,9 \\
\hline $\begin{array}{l}\text { Aktivitási } \\
\text { index* }\end{array}$ & 47,8 & 55,2 & 46,2 & 48,3 & 55,5 & 46,6 & 47,3 & 50,0 & 46,7 \\
\hline & & & & & & & & & \\
\hline Mezógazdaság & 15,3 & 3,0 & 18,5 & 8,0 & 0,7 & 9,9 & 7,1 & 0,5 & 10,4 \\
\hline Ipar & 38,1 & 36,3 & 38,6 & 32,7 & 23,6 & 35,0 & 31,5 & 22,5 & 36,0 \\
\hline Tercier szektor & 46,5 & 60,7 & 42,9 & 59,3 & 75,7 & 55,1 & 61,4 & 77,0 & 53,6 \\
\hline $\begin{array}{l}\text { Aktivitási } \\
\text { index* }\end{array}$ & 43,6 & 45,5 & 43,2 & 34,2 & 37,3 & 33,5 & - & - & - \\
\hline
\end{tabular}

* aktivitási index: az aktív keresök aránya a lakónépességben

Forrás: 1990-es megyei népszámlálási kötetek (KSH 1991-1992); Mikrocenzus 1996. A népesség és a lakások jellemzöi (KSH 1997); A GDP területi megoszlása 1995-ben (KSH 1997) alapján saját számítások. 
Az agrárszektor - a mezőgazdaság szocialista átszervezése és a vidéki iparosítás következtében - már a '60-as évek folyamán elvesztette a nemzetgazdaságban korábban betöltött vezetö szerepét. A '70-es évek közepén az ipari foglalkoztatás is csúcspontjára ért, a '80-as évek elejére pedig - mindössze 15 évnyi ipari primátus után - országos szinten közel kiegyenlítődött a szekunder és a tercier szektor foglalkoztatási szerepe. Az EU-országokhoz képest egészen a rendszerváltásig lényegesen nagyobb maradt azonban a mezőgazdaság jelentősége, amely a falusi iparosítással egyưtt - nemzetközileg is egyedưlálló módon - meghatározó szerepet volt képes játszani a '70-'80-as évek viszonylagos falusi modernizációjában.

A foglalkozási szerkezet regionális különbségei - fokozatos csökkenésük ellenére mindvégig jelentősek maradtak. Budapest fejlődése általában tíz évvel megelözi a vidéki átlagot: míg a fővárosban már a '70-es évek végén, addig vidéken csak a '80as évek második felében jutott vezetó foglalkoztatási szerephez a szolgáltató szektor. A megyék fejlödésének eltérö ütemét mutatja, hogy a rendszerváltáskor akadt még négy olyan egység, ahol az ipari foglalkoztatás volt a legnagyobb; hogy Bács-Kiskunban még 30\% fơlötti részesedésü volt a mezőgazdaság, s hogy az e tekintetben is lemaradt Szabolcs-Szatmár-Beregben az ipar részaránya még az 1980as évtizedben is növekedett. (Kistérségi szinten tarkább a kép: minden nyolcadik statisztikai kistérségben még a mezőgazdaság, minden negyedikben pedig az ipar volt a legjelentősebb foglalkoztató az 1990-es népszámlálás adatai szerint.)

Az 1990-es fordulatot követő hat évben - az általános gazdasági visszaesés, majd a lassan újrainduló növekedés közepette - hatalmas szerkezeti átalakulás következett be, amelynek mértéke nem, iránya viszont minden térségben azonos volt. A foglalkoztatás visszaesése a szolgáltatásokat érintette legkevésbé, így a tercierizálódás felgyorsult és minden régióban általánossá vált. A leojelentősebb változás a mezőgazdaságban történt, amelynek foglalkoztatási részesedése alig tơbb mint felére zsugorodott. (Ezt azzal egyutt is igen jelentös változásnak kell tekinteni, hogy az 1990-es felmérés a tsz-ek melléküzemágaiban dolgozó, ipari vagy szolgáltatási tevékenységet végzỏ személyeket is mezőgazdasági foglalkoztatottként vette számba, így az agrárágazat visszaesése a statisztikákban kimutatottnál lényegesen kisebb mértékủ.) Az ipar pozíciói keveset változtak: nagy teruleti differenciák mellett, átlagosan mintegy 4 százalékponttal esett vissza az ágazatban dolgozók aránya. A változások eredményeként napjainkra Magyarország gazdaságának ágazati szerkezete az Európai Unió átlagának felel meg (2. táblázat). Valamennyi megyében a szolgáltatások foglalkoztatási szerepe a legnagyobb, ezt követi az ipar, végül a mezögazdaság. Hasonló a helyzet az értéktermelést tekintve is. A magyarországi ágazati arányok jól illeszkednek a közép-európai régió országainak (Németország, Ausztria, Svájc, Szlovénia, Csehország, Lengyelország, Szlovákia) gazdasági szerkezetéhez is.

A legjelentősebb eltérést az EU-átlagtól a mezõgazdaság még mindig viszonylag nagy részaránya jelenti. Kimondható ugyanakkor, hogy az ágazat a maga 8-10\%-os súlyával immár nem meghatározó szerepũ a magyar gazdasági folyamatokban. (Mindez azzal együtt is igaz, hogy egyrészt az agrárexport ma is jelentös nemzetgazdasági bevételi forrás, másrészt hogy a mezőgazdasági eredetü nyersanyagok feldolgozása valamint a háztartásokban folyó kistermelés révén az agrárfoglalkoztatottakon kívül a lakosság számos egyéb csoportja is rendszeresen közvetlen kapcsolatba kerül az ágazattal.) 
Az ágazati gazdaságszerkezet szerepe a regionális differenciálódásban Magyarországon. Tér és Társadalom, 12. 1998. 1-2. 138-162. p.

TÉT 1998 -1-2

Gyors ténykép 143

\section{TÁBLÁZAT}

A megyék gazdasági szerkezetének néhány jellemzỏ adata 1995-1996

(Characteristic Indices of Economic Structure of Counties, 1995-1996)

\begin{tabular}{|c|c|c|c|c|c|c|c|c|c|c|c|}
\hline \multirow{3}{*}{ Megye } & \multirow[b]{2}{*}{$\begin{array}{l}\text { Megyei } \\
\text { GDP/fo }\end{array}$} & \multirow[b]{2}{*}{$\begin{array}{c}\text { A gazdaság } \\
\text { termelé- } \\
\text { kenystgec }\end{array}$} & \multirow[b]{2}{*}{$\begin{array}{l}\text { Mezogaz- } \\
\text { dasági }\end{array}$} & \multirow[b]{2}{*}{ Ipari } & \multirow[b]{2}{*}{ Tercier } & \multirow[b]{2}{*}{$\begin{array}{l}\text { A mezógaz. } \\
\text { daság }\end{array}$} & \multirow[b]{2}{*}{ Az ipar } & \multirow[b]{2}{*}{$\begin{array}{l}\text { A tercier } \\
\text { szektor }\end{array}$} & \multicolumn{3}{|c|}{ F.gy lakosra jutó } \\
\hline & & & & & & & & & $\begin{array}{c}\text { mezógaz- } \\
\text { dasági }\end{array}$ & ipari & tercier \\
\hline & \multicolumn{2}{|c|}{$\begin{array}{l}\text { az orszdgos átlag } \\
\text { \%aban } 1995\end{array}$} & \multicolumn{3}{|c|}{$\begin{array}{c}\text { keresők aránya az đsszes aktiv } \\
\text { keresőbol } 1996(\%)\end{array}$} & \multicolumn{3}{|c|}{$\begin{array}{l}\text { részesedése az 1995. tvi megyei } \\
\text { GDP-böl (\%) }\end{array}$} & \multicolumn{3}{|c|}{$\begin{array}{c}\text { GDP az országos átlay } \\
\text { \%ában } 1995\end{array}$} \\
\hline Budapest & 178,3 & 164,4 & 0,7 & 23,7 & 75.7 & 0,5 & 22,5 & 77,0 & 12,9 & 128,1 & 224,5 \\
\hline Pest & 71,3 & 66,6 & 6.0 & 31,9 & 62,1 & 6,6 & 39,6 & 53,8 & 65,8 & 89,1 & 62,1 \\
\hline Közponil régió & $142, I$ & 131,6 & 2,4 & 26,4 & 71,1 & 1.5 & 25,4 & 73,0 & 30,9 & $1 / 4,8$ & 169.2 \\
\hline Baranya & 84,6 & 89,9 & 11,4 & 33,1 & 55,4 & 9,3 & 26,6 & 64,1 & 111.1 & 71,5 & 88,4 \\
\hline Bács-Kiskun & 79,0 & 77,2 & 15,8 & 31,5 & 52,6 & 15,8 & 29,6 & 54,6 & 175,9 & 74,3 & 70,2 \\
\hline Békess & 75,9 & 83,3 & 16,2 & 32,5 & 51,3 & 17,4 & 33,3 & 49,3 & 186,2 & 80,5 & 61,2 \\
\hline Borsod-A-Z. & 76,1 & 93,0 & 5,7 & 37,3 & 57,0 & 7,3 & 42,4 & 50,3 & 78,6 & 102,6 & 62,5 \\
\hline Csongrád & 95,6 & 91,1 & 15,3 & 28,9 & 55,7 & 12,3 & 30,5 & 57,2 & 166,3 & 92,5 & 89,1 \\
\hline Fejér & 98,3 & 91,7 & 10,4 & 41,1 & 48,5 & 9,3 & 44,5 & 46,3 & 128,2 & 138,8 & 74,0 \\
\hline Györ-M-S. & 105,7 & 90,2 & 7,8 & 37,7 & 54,5 & 9,1 & 38,5 & 52,4 & 135,2 & 129,2 & 90,0 \\
\hline Hajdú-Bihar & 76,7 & 86.7 & 12,3 & 31,6 & 56,0 & 13,2 & 29,3 & 57,5 & 142,2 & 71,4 & 71,8 \\
\hline Heves & 76,3 & 80,8 & 6,9 & 38,4 & 54,7 & 8,6 & 33,7 & 57,7 & 92,8 & 81,9 & 71,7 \\
\hline Jász-N-Sz. & 77,6 & 84,6 & 12,3 & 34,2 & 53,5 & 12,2 & 36,3 & 51,5 & 133,6 & 89,7 & 65,2 \\
\hline Komárom & 88,4 & 87,6 & 7,0 & 40,6 & 52,4 & 7,2 & 40,6 & 52,3 & 89,1 & 113,9 & 75,2 \\
\hline Nógrád & 61,0 & 71,2 & 5,6 & 39,8 & 54,6 & 8,4 & 34,5 & 57,1 & 72,7 & 67,0 & 56,9 \\
\hline Somogy & 79,8 & 84,5 & 12,5 & 25.4 & 62,1 & 14,2 & 27,3 & 58,5 & 159,6 & 69,3 & 76,0 \\
\hline Szabolcs-Sz-B. & 62,1 & 80,2 & 10,0 & 34,8 & 55,2 & 12,3 & 28,1 & 59,7 & 107,3 & 55,4 & 60,4 \\
\hline Toina & 92,8 & 93,3 & 14,2 & 36,0 & 49,9 & 14,7 & 40,1 & 45,2 & 192,4 & 118,5 & 68,4 \\
\hline Vas & 105,5 & 88,7 & 8,1 & 42,2 & 49,8 & 8,0 & 46,5 & 45,5 & 118,7 & 156,1 & 78,2 \\
\hline Vestaprem & 86,9 & 81,7 & 8,2 & 36,9 & 54.8 & 7,5 & 37,9 & 54,6 & 91,3 & 104,5 & 77,3 \\
\hline Zala & 96,0 & 85,3 & 6,3 & 39,9 & 53,9 & 8,8 & 39,5 & 51,7 & 118,7 & 120,6 & 80.9 \\
\hline Vidék & 83,3 & 86,1 & 10,5 & 35,4 & 54,1 & 10,8 & 35,6 & 53.5 & 127,3 & 94,2 & 72,7 \\
\hline $\begin{array}{l}\text { Sulyozott relativ } \\
\text { szóris (\%) }\end{array}$ & 14.6 & 6.3 & 33.2 & 12,1 & 5.4 & 28,6 & 17,1 & 9.3 & 27,6 & 27,9 & 13,4 \\
\hline Ország együt: & 100,0 & 100,0 & 8,0 & 32,7 & 59,3 & 7,1 & 31,5 & 61,4 & 100,0 & 100,0 & 100,0 \\
\hline
\end{tabular}

Forras: Mikrocenzus 1996. A népesség és a lakások jellemzó; (KSH 1997); A GDP teraleli megoszlása 1995-ben (KSH 1997) alapján sajaj számilıások. 
Az agrár-alapú foglalkoztatás-bỏvités még kisebb regionális szinteken sem tünik reális alternatívának azért sem, mert termékei többségének piaca szük, nehezen bővíthetö, és viszonylag szerény profitot termel. Mindez azon hipotézis megfogalmazását indokolja, hogy nagyobb (megyényi) térségek esetében önmagában nem, kistérségi szinten is csak számos kedvezö körülmény összejátszása esetén, kivételként lehet dinamikus regionális gazdasági fejlödés alapja ez a szektor hazánkban.

Az ipar dinamikahordozó szerepével kapcsolatos elméleti megfontolások egyik része amellett szól, hogy az ipari alapú regionális fejlódés egyre kevésbé lehetséges. A legfontosabb ilyen érv a tercierizálódás általános tendenciája, ami többnyire az iparban dolgozók számának folyamatos fogyását is jelenti. Mindezek következtében regionálisan is egyre kevesebb az esély a korábbiakhoz hasonló súlyú térségi ipari koncentrációk, egyáltalán: bármiféle "ágazati körzet" létrejöttére (Nemes Nagy 1987). A rendszerváltás utáni gazdasági visszaesés (piacvesztés, foglalkoztatáscsökkenés) ráadásul éppen a meglévő iparvidékeinket érintette legérzékenyebben. Ezek zömének hagyományos ágazatai bizonyosan alkalmatlanok a térség fellendítésére. Belsỏ erôforrásokból kicsi az esély ủj típusú ipari körzetek létrejöttére is, mivel a "high-tech" ipar területileg kevésbé koncentrálódik, nem igényli a bőségesen rendelkezésre álló munkaerỏt, viszont magas a tőke-, technológia-, és infrastruktúra-igénye, $\mathrm{s}$ épp ezek az adottságok hiányoznak leginkább Magyarországon.

Más megfontolások ugyanakkor ellentétes irányú következtetéseket támasztanak alá. Ezek közül a legfontosabb, hogy az ipar részarányának csökkenése a termelési értékböl és a foglalkoztatottakból világviszonylatban sem jelenti az ágazat gazdasági jelentöségének visszaesését (Enyedi 1996). Másrészt már legalább húsz éve folyik a hagyományos (és sok esetben igen korszerü) ipari termelés kitelepülése a fejlett országokból a perifériákba, ami ott kifejezetten dinamizáló hatású is lehet. Bizonyság erre egy friss, hozzánk közeli példa, Írország, amely 1990-1994 között e tekintetben világelsőként - több mint 50\%-kal növelte ipari termelését, nem kis részben ennek köszönheti kimagasló gazdasági növekedését, aminek eredményeként mára az egy före jutó GDP nagyságát tekintve megelózte Nagy-Britanniát. Fontos leszögezni azt is, hogy - mint azt egyebek mellett İ́rország, Dánia, Közép-Itália fejlődése bizonyítja - nemcsak a "high-tech", hanem számos hagyományos iparág (bútor-, játék, vagy divatáru-gyártás stb.) is a regionális dinamika alapjává válhat, a piacbövités lehetöségei pedig nemzetközileg leginkább a posztmateriális jellegú szabadidö-, és környezetvédelmi "iparokban" mutatkoznak (Enyedi 1996). Az EU legfejlettebb régiói közull számos közeli német és észak-olasz térség jelentős ipari zóna, s ezekből, de akár távolabbról is könnyen kitelepülhetnek bizonyos ipari kapacitások az európai félperiféria egyik legstabilabb országának számító Magyarországra, így hazánkban is valószinüsíthető relative nagyobb ipari súllyal rendelkezỏ dinamikus körzetek kialakulása. 
Az ágazati gazdaságszerkezet szerepe a regionális differenciálódásban Magyarországon. Tér és Társadalom, 12. 1998. 1-2. 138-162. p.

TÉT 1998 - 1-2

Gyors ténykép

145

\section{Az ágazati jelleg koncentrálódása a magyarországi régiók gazdaságában}

Eddigi elméleti megállapításaink tapasztalati ellenörzését a magyar regionális gazdaságszerkezeti mutatók változásának idősoros modellezése, és a NUTS-I-II szintü EU-régiókra elvégzett, azonos tartalmú számításokkal való összevetése révén kíséreltuik meg. Elsö lépésként azt kellett eldöntenünk, hogy mekkora részesedés esetén tekintünk meghatározó jelentőségünek egy ágazatot valamely térség gazdaságában. Az EU NUTS-II szintü régióinak 1992-es, illetve a magyar megyék 1996-os foglalkozási szerkezetét megvizsgálva, a relatív nagyságot tekintve: csak három olyan (görög) NUTS-II-régió van, ahol 1992-ben a mezögazdaság volt a legnagyobb foglalkoztató, és csak egy olyan magyar megye (Vas), ahol 1995-ben az ipar szerepe volt a legjelentösebb a GDP létrehozásában - egyébként mindkét szempontból és mindenhol a szolgáltatások szerepe a legnagyobb.

Az adatok tükrében tehát az "ipari térség", "agrárkörzet", illetve a velük szinonim fogalmakat ma már csak relativ értelemben indokolt használni: azon régiók megnevezésére, ahol az adott ágazat érzékelhetően nagyobb jelentỏségủ a régió gazdaságán belül, mint az országos, vagy az európai gazdaság átlagában. A mezőgazdaság esetében már a $10 \%$ feletti foglalkoztatási részesedést is ilyennek kell tekintenünk, amely épp megfelel a jelenlegi magyar vidéki átlagnak, az EU átlagának pedig éppen a kétszerese. Az EU NUTS-II. régióinak közel 30\%-a volt ilyen, kevés kivétellel a félperiféria országaiból (szinte az összes görög és portugál, számos dél-spanyol és dél-olasz térség, illetve Írország és néhány finn vidék), a kivételek pedig a centrum országok fejletlenebb területei közủl kerültek ki. Magyarországon - mint azt a 2. táblázat is mutatja - az alföldi és a dél-dunántúli megyék sorolódtak ebbe a csoportba 1996-ban.

Az ipar aránya a foglalkoztatottakból a NUTS-II régiók, illetve Magyarország átlagában is hasonló ( 31 és 33\%), s mi az erösebb "ipari jelleg" alsó határát a 35 , illetve a 37\%-os értéknél húztuk meg. Ebbe a körbe "mezögazdasági" kategóriához hasonló számú térség került, ám az ipari részarány szóródásának terjedelme jóval kisebb (35 és 47\% közötti), összetételük pedig kevésbé egységes. Az "európaiak" több mint fele (27) ugyan német, osztrák illetve észak-olasz régió, a fejlett térségek mellett ugyanakkor - országuk átlagát tekintve - kifejezetten elmaradottnak minösülök is vannak közöttuik. Magyarország esetében is hasonló a helyzet: a dinamikus Észak-Dunántúlon kívül az egykori ipari tengely "rozsdásodó" keleti felének (Nemes Nagy 1997) területei vannak e csoportban.

A magyar régiók eltérỏ dinamikájảnak gazdaságszerkezeti összefüggéseit kutatva fontos kérdés, hogy az általános tercierizálódás közepette az ágazati szerkezetek - az európai modellhez hasonlóan - homogenizálódtak-e a rendszerváltás elötti, illetve utáni időszakban. Az általunk alkalmazott eljárás az egyes ágazatok területi koncentrálódását egyetlen méröszámmal jellemző ún. Hoover-indexek kiszámítása volt az 1960., 1970., 1980., 1990., évi népszámlálások, illetve az 1996-os mikrocenzus időpontjában. ${ }^{5} \mathrm{Az}$ eredmények (1. ábra, 3. táblázat) tanúsága szerint 1990 után éles fordulat következett be Magyarországon a gazdaságszerkezet területi egyenlötlenségeinek alakulásában is. A tercier szektor folytatódó térnyerése ellenére ugyanis megállt a korábbi kiegyenlitődés: minden nemzetgazdasági ág 
területi egyenlötlenségei nöttek, és az ágazati szerkezet egészét tekintve is differenciálódás következett be. Más szóval a megyék gazdasági karaktere sajátosabbá vált: a visszaesés és a fejlödés az egyes ágazatokon belül és területenként is eltérỏ mértékủ volt az elmúlt idöszakban, növekedett tehát az egyes szektorok régión belüli sajátosságainak a szerepe.

\section{1. ÁBRA}

A foglalkoztatottság megyék közötti különbségeinek alakulása a három fö nemzetgazdasági szektorban 1960-1996

(fönt: Budapesttel együt, lent: Budapest nélkül)

(Trends in Spatial Differences of Unemployment in the Three Main Sectors)

(Top: including Budapest, below: excluding Budapest)
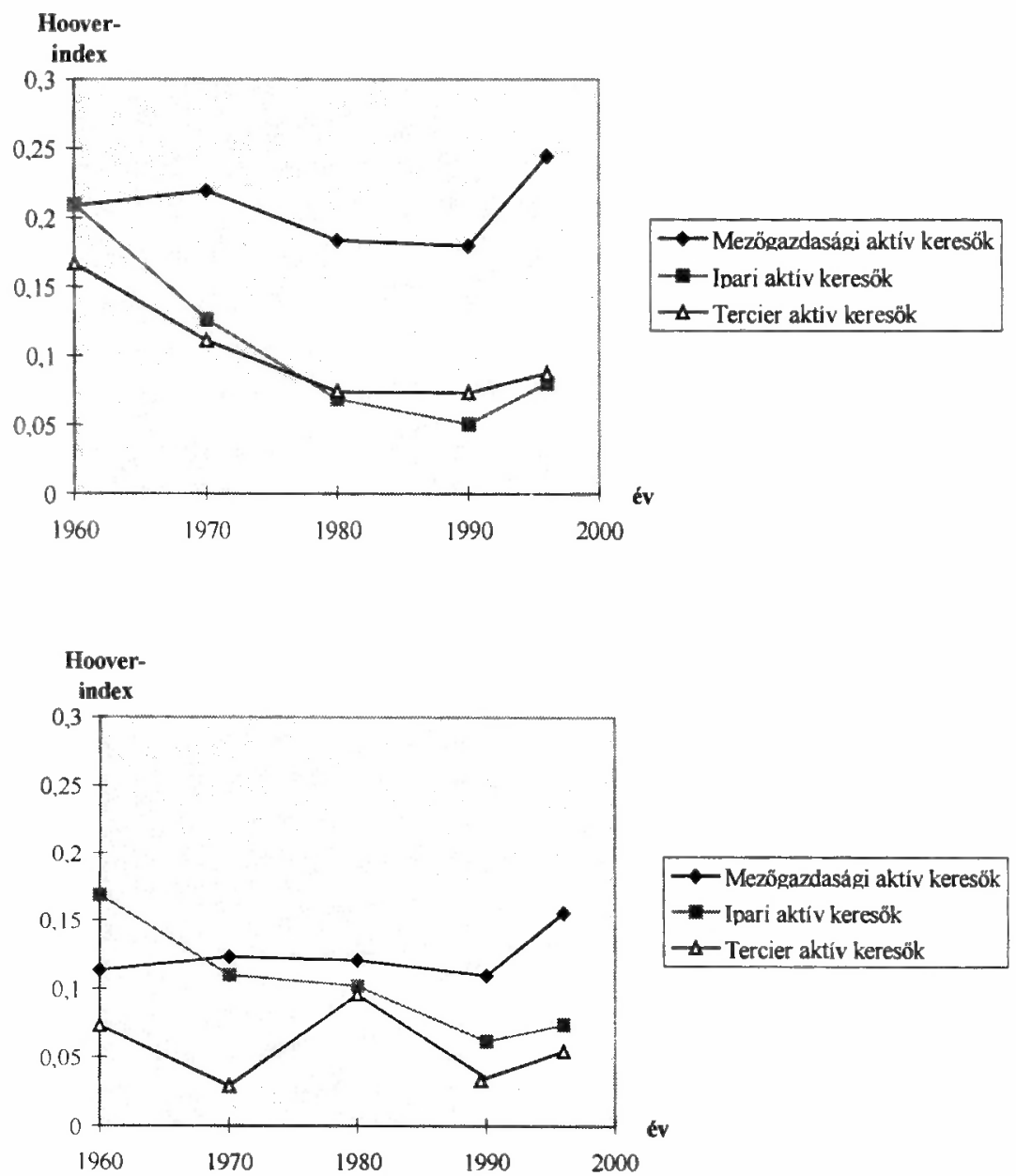

Forrás: Mikrocenzus 1996. A népesség és a lakások jellemzỏi (KSH 1997); A GDP területi megoszlása 1995-ben (KSH 1997) alapján saját számítások 
Az ágazati gazdaságszerkezet szerepe a regionális differenciálódásban Magyarországon. Tér és Társadalom, 12. 1998. 1-2. 138-162. p.

Mindenképpen szükséges kiemelni a budapesti gazdaság ágazati összetételének hatását, mert az eredmények az esetek többségében jelentősen eltéröek voltak attól függően, hogy a fövárost is szerepeltettük a vizsgálatban, vagy csak a 19 megye adataival dolgoztunk. A sajátos gazdasági karakterü, nagy népesség-súlyú Budapest, az esetek többségében növelte a szóródást: a Hoover-index országra vonatkozó értékei általában nagyobbak, mint a vidéki mutatóké.

Az egyes ágazatok szóródásának arányai is jelentős mértékben különböznek a két számításban. A legnagyobb - és 1990 óta legeröteljesebben növekedö - területi koncentráltságú ágazat a foglalkozási szerkezetet tekintve mindkét esetben az agrárszektor. Kis nemzetgazdasági súlyából eredöen azonban - mint azt a 3. táblázat mutatja - 1996-ban már ez az ágazat befolyásolta legkevésbé a gazdaságszerkezet regionális sajátosságait.

\section{TÁBLÁZAT}

A foglalkozási szerkezet területi differenciáltsága és ágazati megoszlása a Hoover-index értékei alapján 1960-1996 (\%)

(Spatial and Sectoral Differentiation of the Labour Market by the Hoover index, 1960-1996)

\begin{tabular}{|l|c|c|c|c|c|}
\hline Megyék + Budapest & 1960 & 1970 & 1980 & 1990 & 1996 \\
\hline Heterogenitás összesen* & 19,72 & 14,43 & 9,25 & 8,12 & 9,79 \\
\hline A mezőgazdaság részesedése & 40,6 & 37,6 & 37,5 & 34,1 & 20,0 \\
\hline Az ipar részesedése & 36,1 & 38,1 & 31,0 & 23,8 & 26,9 \\
\hline A tercier szektor részesedése & 23,3 & 24,3 & 31,5 & 42,1 & 53,1 \\
\hline Megyék, Budapest nélkül & 1960 & 1970 & 1980 & 1990 & 1996 \\
\hline Heterogenitás összesen (\%)* & 11,89 & 9,15 & 10,41 & 5,96 & 7,15 \\
\hline A mezögazdaság részesedése & 45,9 & 41,2 & 26,3 & 34,0 & 21,6 \\
\hline Az ipar részesedése & 38,9 & 48,9 & 40,5 & 40,4 & 36,3 \\
\hline A tercier szektor részesedése & 15,2 & 9,9 & 33,2 & 25,6 & 42,1 \\
\hline
\end{tabular}

* Osszes heterogenitds: a három ágazat Hoover-indexeinek súlyozott állaga

Forrás: Mikrocenzus 1996. A népesség és a lakások jellemzöi (KSH 1997); A GDP területi megoszlása 1995-ben (KSH 1997) alapján saját számítások.

A vidéki megyéket tekintve - a nemzetközi viszonyoknak megfelelóen - az ipar területi szóródása következik a mezőgazdaság után, ám Budapesttel egyưutt a tercier szektor valamivel megelözi (2. táblázat). A különbség felhívja a figyelmet a föváros szolgáltató szektorának kiemelkedö jelentöségére. Legalább ekkora a jelentősége azonban annak, hogy a gazdaságszerkezet megyék közötti egyenlötlenségeinek kialakitásában az ipar szerepe még ma is igen jelentös, a tercier szektorral közel azonos súlyú. $\mathrm{Az}$ összességében viszonylag kismértékü vidéki ipari visszaesés aránylag csekély koncentráció-növekedéssel járt - ám figyelembe kell venni azt is, hogy eközben az utóbbi 5-7 év során hatalmas arányú területi átrendezódés következett be az ipari termelésben, amelynek lényege az észak-dunántúli megyék ipari súlyănak növekedése a keleti országrésszel szemben. (Nemes Nagy 1997)

$\mathrm{Az}$ értéktermelés ágazati szerkezetének 1995-ös területi egyenlötlenségeire vonatkozó számítások eredményei még jobban kiemelik az előzőekben megfogalmazott sajátosságokat. A mezógazdaság GDP-n belüli részesedésének 
szóródása kisebb, mint azt foglalkoztatási szerepét tekintve tapasztaltuk, így a gazdaságszerkezet területi eltéréseit 1995-ben a megyékre vonatkozóan 17, míg az ország egészét tekintve csak $8 \%$-ban okozza ez a szektor.

A tercier szektor jövedelemtermelésének területi különbségeit tekintve Budapest különleges helyzete a legszembeötlöbb. A fővárost is figyelembe véve az egy fŏre jutó tercier GDP szóródása még a mezógazdaságot is felülmúlja, így a területi ágazati különbségek közel háromnegyede (73,3\%) ebből adódik, s ennek köszönhető az is, hogy az egy före vetített ágazati GDP szóródása (a három Hoover-index súlyozott átlaga) közel duplája a foglalkozási szerkezet hasonló mutatójának (19,5 illetve 9,8\%). A vidéki Magyarország esetében - a foglalkoztatottsághoz hasonlóan - minimális a tercier szektor jövedelmeinek szóródåsa, s a teljes ágazati heterogenitásnak is csak kevesebb, mint $37 \%$-a köthetó a szolgáltatásokhoz. ${ }^{6}$ A tercier szektor súlyának országos, illetve "vidéken" belüli szóródását vizsgálva hasonló jellegủ eltérések mutathatók ki más, lakosságszárnához képest kiugróan népes fôvárosi térséggel rendelkezô európai ország (Franciaország, Ausztria, Görögország, Portugália) esetében is. Magyarország helyzete mégis kưlönleges, mert e kulönbség sehol sem olyan megdöbbentően nagymértékü, mint nálunk: a "vidéki" régiókra számitott Hoover-index értéke az EU országaihoz képest is az alacsonyabbak közé tartozik, ugyanakkor a Budapesttel együtt adódó szóródás pedig valamennyi EU-országénál magasabb, és az sem fordul elö máshol, hogy a legnagyobb területi koncentráció a tercier szektorhoz kötódjön.

Az ipari jövedelmek szóródása egyértelmüen arra utal, hogy léteznek ipari jellegủ körzetek a mai Magyarországon. Az egy fơre jutó ipari GDP vidéki differenciáltsága lényegesen nagyobb, mint az ipari foglalkoztatottságé. A Hoover-index értéke európai összevetésben ugyan nem tartozik a legmagasabbak közé, ám nem sokkal marad el a mezógazdaságétól. Az ágazat a gazdaságszerkezet vidéki területi különbségeinek közel felét $(46,3 \%)$ okozza, megelözve a tercier szektort - ami meglehetösen ritkának számit Európában.

$\mathrm{Az}$ ipari jövedelmek differenciálódására vonatkozóan sikerült egy hosszabb idősort előállitanunk. Az 1995-ös megyei ipari GDP-adatokból a KSH által 1964 óta évente közölt termelési volumenindexek segítségével jó közelítéssel becsülhetõ volt az 1990-es, 1980-as és 1970-es termelési érték (1995-ös árakon). ${ }^{7}$ 1960-ra vonatkozóan Barta Györgyi ipari nemzetijövedelem-becslését felhasználva sikerlilt a megfeleló információkhoz jutnunk (Barta 1977) ${ }^{8}$ Az eredmények szerint $a z$ ipari jövedelmek területi szóródása folyamatosan meghaladta az ipari foglalkoztatottságét, s e különbség mértéke - a 19 megyét tekintve - a korábbi évtizedek folyamatos csökkenése után 1990 óta újra növekedésnek indult. Ez arra utal, hogy az iprrnsolottabb meg'ćkben az ágazat termelékenysége és/vagy a foglalkoztatottság magasabb, mint a kisebb volumenü iparral rendelkezö területeken.

Összegezve: az 1990 óta lezajlott gazdaságszerkezeti átrendezödés területileg egyenlötleniul ment végbe, $s$ - a gazdasági fejlettség és fejlỏdés területi különbségeinek növekedésével (Enyedi 1996, 1997, Nemes Nagy 1996, Rechnitzer 1993) párhuzamosan - a regionális gazdaságszerkezet kiegyenlitődésének több évtizedes trendje is megfordult. A mezőgazdaság esetében azonban az országos (illetve vidéki) átlagnál sokkal jelentõsebb (akár 2-2,5-szeres) részarány sem jelenti az ágazat dominanciáját a regionális gazdaságon belül, mert az ipar és a tercier 
Az ágazati gazdaságszerkezet szerepe a regionális differenciálódásban Magyarországon. Tér és Társadalom, 12. 1998. 1-2. 138-162. p.

TÉT 1998 1-2

Gyors ténykép

149

szektor gazdasági súlya még ezekben a térségekben is jelentősebb az agrárágazaténál. Nyilvánvalóvá vált emellett az is, hogy Budapest, illetve a vidéki Magyarország gazdaságfejlödési irányai alapvetöen eltérnek egymástól.

\section{A gazdaságszerkezet és jövedelemtermelö-képesség regionális összefüggései}

Az elmúlt évtizedek nemzetközi és hazai vizsgálatainak egybehangzó következtetése szerint a modern gazdaságokban az ágazati gazdaságszerkezet és a gazdasági fejlettség között gazdasági ciklusoktól és fejlödési modellektől függően eltéro jellegü és szorosságú, kimutatható sztochasztikus - a sajátos természeti és társadalmi körülmények, illetve történelmi hatások által befolyásolt - kapcsolat van (Nemes Nagy 1987). Az ágazati arányok magyarázóereje azonban Európában egyre kisebb a fejlettségi különbségek szempontjából. Egy, az 1980-as Európai Gazdasảgi Közösségi régiókra vonatkozó vizsgálat adatai szerint 1950 és 1970 között az ipar esetében +0,61-ról +0,32-ra, míg a tercier szektorban +0,62-ról +0,55-ra csökkent a lineáris korrelációs együttható értéke, miközben a mezőgazdasági jelleg mindkét idöpontban a fejletlenséget tükrözte $\left(-0,6\right.$ és $-0,8$ közötti értékekkel). ${ }^{9}$ 1992-re vonatkozó saját számításaim e tendenciák folytatódását igazolják. Az idöközben 15 tagúra bövült Európai Unió 68 , NUTS-I szintü nagyrégióját ${ }^{10}$ vizsgálva a mezőgazdaság magas foglalkoztatási szerepe továbbra is egyértelmüen, bár valamelyest gyengébb erỏvel $(-0,58)$ az elmaradottságra utal. Az ipar gazdasági súlya önmagában véve már egyáltalán nem meghatározó a területi fejlettség szemnontjából $(+0,15)$. Egyre lazább a kapcsolat $(+0,38)$ a gazdasági fejlettség és a szolgáltatások foglalkoztatási szerepe között is, ami - az iparhoz hasonlóan - azt valószínüsíti, hogy a tercier szektor belsö szerkezete, illetve egyéb, nem-strukturális tényezök szerepe válik egyre fontosabbá a területi gazdasági fejlettség színvonalának meghatározásában.

Alacsonyabb fokú területi aggregációban (NUTS-II. régiókra) elvégezve e számításokat, kiderült, hogy egyes országcsoportokon belül eltérö összefüggések adódhatnak a szekunder és a tercier szektor aránya, illetve a gazdasági fejlettségi szint között ${ }^{11}$ (4. táblázat). Különösen nagy az ipar szerepének szóródása: magasabb gazdasági részesedése csak a dél-európai államok: Görögország, Olaszország, illetve Spanyolország és Portugália régiói esetében jelent viszonylagos fejlettséget. $\mathrm{Az}$ országok többségében már korrelálatlan az ipar részaránya illetve a gazdasági fejlettség értéke, a skandináv államok esetében pedig kifejezetten a relatív elmaradottságra utaló faktor a jelentös ipari súly. A szolgáltatások és a gazdasági fejlettség korrelációja általában pozitív elöjelü, ám az esetek többségében nem tekinthetö szignifikánsnak. A tercier ágazat mindenütt 50\%-ot meghaladó gazdasági súlya miatt - bár az erösen tercierizált nagyvárosi agglomerációk zöme a regionális fejlettségi rangsor élcsoportjában foglal helyet - nem tekinthető differenciáló szektornak e regionális szinten sem. Ez azonban nem zárja ki, sôt éppen kiemelésre érdemesíti a szolgáltató szféra belső arányainak - a hagyományos tercier alágazatok (közoktatás, egészségügy, közigazgatás stb.), illetve a "kvaterner" jellegủ fejlett uizleti szolgáltatások, $\mathrm{K}+\mathrm{F}$, felsöoktatás, információgazdaság stb. részesedésében megnyilvánuló - fejlettségi indikátor-szerepét. 
Az ágazati gazdaságszerkezet szerepe a regionális differenciálódásban Magyarországon.

Tér és Társadalom, 12. 1998. 1-2. 138-162. p.

Az ipari jellegủ régiók nálunk is a fejlettségi rangsor pólusain helyezkednek el. A legmagasabb - $37 \%$ fölötti - ipari foglalkoztatotti aránnyal rendelkezö térségek egyik csoportját a dinamikusabb Észak-Dunántúl megyéi - sorrendben Vas, Fejér, Komárom-Esztergom, Zala, Györ-Moson-Sopron - alkotják; míg a másik csoportba korábbi ipari tengely válságtérségei: Nógrád, Heves, és Borsod-Abaúj-Zemplén kerültek. Abban az adatsorban, amely az ipari termelés növekedésének évi átlagos ütemét mutatja 1990 és 1996 között (Nemes Nagy 1997) az iparosodott és fejlett megyecsoport tagjai ugyancsak az élen állnak, míg Nógrád és Borsod épp az átlagost is jóval meghaladó visszaesése révén emelkedik. Ez arra utal, hogy az ipar dinamikájának alakulása az 1990-es években egyértelmüen szinkronban volt a vidéki régiók területi differenciálódásával.

\section{TẢBLÁZAT}

A lineáris korrelációs együttható értékei egyes európai országok régióinak egy före vetített GDP-je és ágazati gazdaságszerkezeti arányaik között (1992)

(The Value of Linear Correlation Coefficient Indicating Relations between GDP/capita Indices and Sectoral Structure in Several European Countries, 1992)

\begin{tabular}{|c|c|c|c|c|c|c|c|}
\hline \multirow[t]{2}{*}{$\begin{array}{c}\text { Ország, } \\
\text { országcsoport }\end{array}$} & \multirow{2}{*}{$\begin{array}{l}\text { Terulleti } \\
\text { egységek } \\
\text { száma (db) }\end{array}$} & $\begin{array}{c}\text { Mezögaz- } \\
\text { dasági }\end{array}$ & Ipari & Tercier & $\begin{array}{c}\text { Mezỏgaz- } \\
\text { dasági }\end{array}$ & Ipari & Tercier \\
\hline & & \multicolumn{3}{|c|}{ keresők aránya (\%) } & \multicolumn{3}{|c|}{ GDP aránya (\%) } \\
\hline $\begin{array}{l}\text { Svédország és } \\
\text { Finnország }\end{array}$ & 14 & $-0,73$ & $-0,52$ & $+0,90$ & $-0,66$ & $-0,79$ & $+0,94$ \\
\hline Benelux államok & 24 & $-0,50$ & $-0,10$ & $+0,24$ & $-0,58$ & $+0,04$ & $+0,14$ \\
\hline Franciaország & 22 & $-0,49$ & $+0,11$ & $+0,18$ & $-0,27$ & $+0,16$ & $-0,05$ \\
\hline $\begin{array}{l}\text { Spanyolország és } \\
\text { Portugália }\end{array}$ & 25 & $-0,67$ & $+0,32$ & $+0,20$ & $-0,73$ & $+0,14$ & $+0,23$ \\
\hline Olaszország & 20 & $-0,86$ & $+0,54$ & $+0,12$ & $-0,80$ & $+0,60$ & $-0,42$ \\
\hline Németországa) & 31 & $-0,44$ & $-0,26$ & $+0,34$ & $\ldots$ & $\ldots$ & $\ldots$ \\
\hline Ausztria & 9 & $-0,85$ & $-0,37$ & $+0,71$ & $-0,88$ & $-0,31$ & $+0,53$ \\
\hline $\begin{array}{l}\text { Ausztria Bécs } \\
\text { nélkül }\end{array}$ & 8 & -0.78 & +0.09 & $+0,37$ & $-0,89$ & +0.17 & +0.11 \\
\hline Görögország & 13 & $-0,35$ & $+0,62$ & $+0,08$ & $-0,40$ & $+0,63$ & $-0,12$ \\
\hline $\begin{array}{l}\text { Görögország } \\
\text { Attika nélkül }\end{array}$ & 12 & $-0,11$ & $+0,57$ & $-0,25$ & $-0,17$ & $+0,69$ & $-0,42$ \\
\hline Magyarország ${ }^{\text {b) }}$ & 20 & $-0,42$ & $-0,31$ & $+0,56$ & $-0,56$ & $-0,16$ & $+0,45$ \\
\hline $\begin{array}{l}\text { Magyarország } \\
\text { Budapest nélkul }^{\text {b) }}\end{array}$ & 19 & $+0,05$ & $+0,31$ & $-0,45$ & $-0,16$ & $+0,50$ & $-0,50$ \\
\hline
\end{tabular}

a) volt nyugatnémet tartományok

b) 1995

Forrás: Regions. Statistical Yearbook 1995. (EUROSTAT, 1996) alapján saját számítások

A korrelációszámítások ugyanakkor minden eddiginél szembetünőbb módon hívják fel a figyelmet Budapest és a megyék teljesen kưlönbőző ágazati szerkezeten alapuló gazdasági fejlödésére. Míg a budapesti agglomeráció fejlódése az 1990-es években döntöen a tercier szektor dinamikájára alapozódik, a vidéki térségek differenciálódásában az iparnak van meghatározó szerepe; s az 1990 óta látványosan nekilendülỏ vidéki régiók modernizálódása szinte kivétel nélkül ipari ezen belül feldolgozóipari - alapon történik. 
Az ágazati gazdaságszerkezet szerepe a regionális differenciálódásban Magyarországon. Tér és Társadalom, 12. 1998. 1-2. 138-162. p.

TÉT 1998 - $1-2$

Gyors ténykép

151

Az ország 20 területi egységére (19 megye és Budapest) számítva a mezőgazdaság súlya és az egy före vetített GDP nagysága között közepesen erős negatív korrelációs érték adódik; az ipar arányával az összefüggés negatív elöjelủ, de nem tekinthető szignifikánsnak; míg a tercier jelleg és a fejlettség korrelációja közepes erősségú és pozitív irányú, akár a foglalkoztatottság, akár a GDP ágazati arányait tekintjük az ágazati jelleg mérőszámának. Ezek az irányok és értékek az EU-országok hasonló adatait tekintve érzékelhetően az osztrák-német "modellel" mutatnak rokonságot.

Ám Budapestet kihagyva az adatsorból nemcsak a kapcsolat erössége, hanem az iránya is megváltozik. A mezőgazdaság aránya nem feleltethetö meg egyértelmüen a megyék közötti fejlettségi különbségeknek, s ebben - a nyugati analógiák tükrében azt kell meglepönek tekintenünk, hogy a mezőgazdasági jelleg nem a fejletlenség indikátora. A kapcsolat hiánya ugyanakkor bizonyíték arra, hogy a nagyobb területi egységek szintjén kizárt az agrárszektorra alapozódó gazdasági dinamika lehetõsége csakủgy, mint a mezögazdasági foglalkoztatás növelése. (Ez azzal együtt is igaz, hogy valószinüleg jóval többen húznak jövedelmet az agrárszektorból, mint amennyi a fóallású mezőgazdasági munkavállalóknak az aktív keresökön belül statisztikailag kimutatott részesedése.)

Még jelentősebb az eltérés a Budapesttel együtt, illetve nélküle számitott korrelációk között az ipar és a tercier szektor esetében, ahol az összefúggések pontosan az ellentettjeik egymásnak. A tercier jelleg és a fejlettség között a megyék esetében tapasztalt negatív korreláció szinte párhuzam nélküli az EU-országokban. Az ipari részarány és a GDP-nagyság közötti $+0,5$ körüli pozitiv korrelációs értéknek pedig különösen a nagysága meglepö annak tưkrében, hogy a még ma is ipari jellegủ Borsod és Nógrád megye a GDP-rangsor végén található. Az ipari jelleg és a területi fejlettség rangsorának elején azonban egyaránt a legdinamikusabb észak- és nyugat-dunántúli megyék állnak, ami szintén arra utal, hogy e térség viszonylag gyors talpraállásának alapját, fejlỏdésük megindulásának meghatározó elemét az ipar sikeres átalakulása képezte. (A szolgáltatások csak néhány nagy népességi súlyú megyeszékhellyel vagy jelentős idegenforgalommal rendelkezö megye - Baranya, Csongrád, Somogy - viszonylag jobb pozíciójának kialakitásában játszhattak lényeges szerepet.) Az ipar azzal egyuitt is jelentôsebb tényezöje a megyék differenciálódási folyamatainak, hogy gazdasági súlya minden megyében a szolgáltatásoké alatt marad. A gazdaságszerkezet és a fejlettség között "vidéki" viszonylatban tapasztalt ezen összefüggésrendszer meglehetösen sajátnsnak számit Európában: egyedüli párhuzamát Görögországgal (különösen a vidéki Görögországgal) találtuk (4. táblázat). ${ }^{12}$

A kétféle számítás eredményei között tapasztalható különbséget kizárólag a fővárosnak a megyékétől eltérő gazdasági karaktere okozza. Igaz, a nagyvárosi agglomerációk gazdaságszerkezete mindenütt különbözik többé-kevésbé a többi régióétól, ám egyetlen vizsgált európai ország esetében sem találkoztunk ekkora mértékü különbséggel. A megyékkel összehasonlítva Budapest valamennyi ágazatának a helyi gazdaságon beluli részaránya szélsőséges értékủ, így a fóváros teljesen felborítja a vizsgált változók egyébként normálisnak tekinthetỏ eloszlását (2. ábra). 


\section{2. ÁBRA}

A gazdasági fejlettség az ipari jelleg függvényében a megyékben (1995) (Economic Performance of Counties in the Context of Industrial Development, 1995)

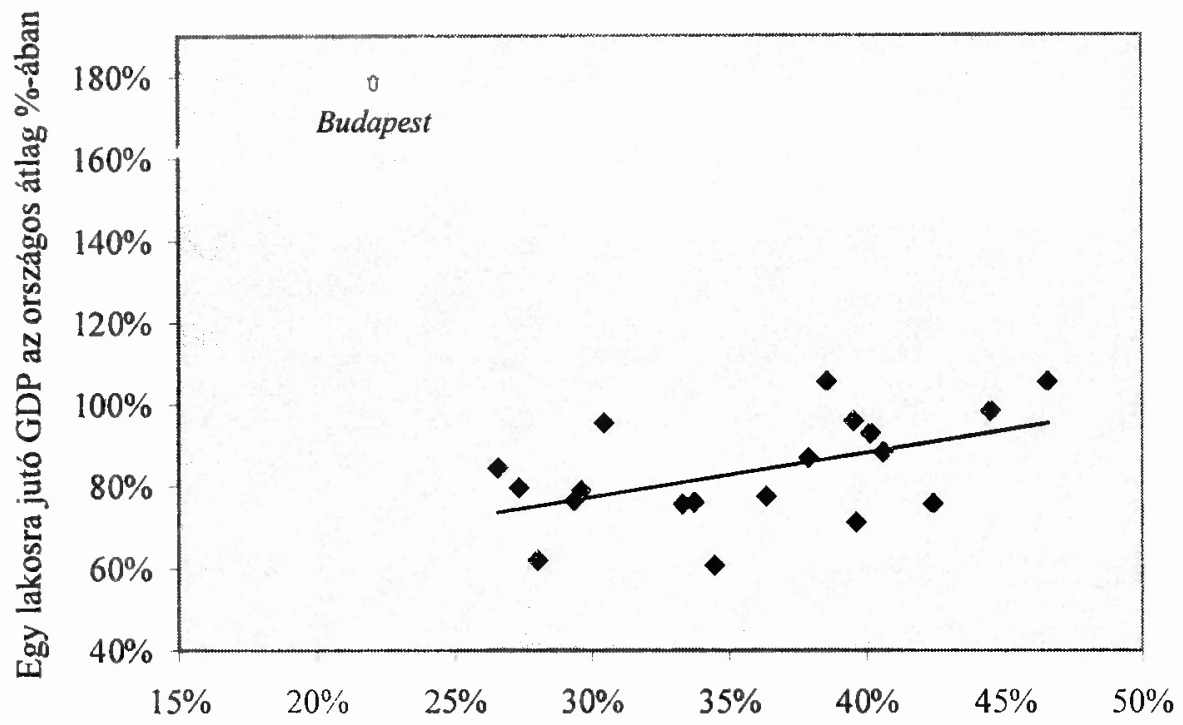

Az ipar aránya a GDP-bỏl

Forrás: A bruttó hazai termék (GDP) területi megoszlása 1995-ben (KSH 1997)

Ezek a gazdaságszerkezeti különbségek egyik lényegi elemét jelentik annak a szakmai közhelyként emlegetett - ténynek, mely szerint az ország területi tagoltságának legfontosabb dimenziója a föváros-vidék dualizmus, azaz a centrumperiféria viszonyrendszer, a második legfontosabb pedig a nyugat-keleti regionális megosztottság. A fôváros és a vidéki átlag bő kétszeres fejlettségi különbségében megnyilvánuló centrum-periféria viszonynak a tercier szektor gazdasági súlyában és belsõ ágazati összetételében meglevõ eltérések feleltethetōk meg. A vidéki Magyarországot megosztó fejlettségi differenciák mögött viszont - amelyek maximális terjedelmét a vidéki átlag 73 (Nógrád, Szabolcs), illetve 127\%-a (GyőrSopron, Vas) jelenti - az ipar dinamikájának és szerkezetének területi különbségei hủzódnak meg elsösorban.

A fỏvárosi tercier gazdaság országosan egyedülálló helyzetének bizonyitékaként számos egyéb összefưggés is felhozható. Jellemzö például, hogy a GDP területi egyenlőtlenségei az ország egészét tekintve az EU-országokhoz képest kiugró mértékủek, ám a szórás közel kétharmadát Budapest kimagasló GDP-értéke okozza. Csak a megyéket tekintve a fejlettségi különbségek mértéke (14,8\%) európai összehasonlításban nem tartozik a legnagyobbak közé. Az ország lakosságának bő 18\%-át, illetve a foglalkoztatottak 20,3\%-át adó fỏváros a GDP-ből már 33,4\%-kal részesedik, ennek a jövedelemnek legföbb forrása a tercier szektor: Budapest tercier 
Az ágazati gazdaságszerkezet szerepe a regionális differenciálódásban Magyarországon. Tér és Társadalom, 12. 1998. 1-2. 138-162. p.

TÉT 1998 -1-2

Gyors ténykép

153

keresöi az e szektorban foglalkoztatottak $26 \%$-át adják, a tercier GDP-böl pedig $42 \%$-os a föváros részesedése, ami az országos ágazati átlagot $61,5 \%$-kal meghaladó termelékenységet is jelent. A tercier szektor termelékenységében Budapesten kivül csak egyetlen megye (Baranya) éri el az országos átlagot, míg az egy före jutó tercier GDP-t tekintve Budapest 225\%-os értéke után 90\%-kal következik az elsö megye (Györ-Moson-Sopron).

Ennek fö oka, hogy éppen a tercier szektor legdinamikusabb alágazataiban a legszembetünóbb a föváros magas részesedése (Raffay 1997). Az innovációban is élenjáró gazdasági-üzleti tanácsadással, vagy a számítástechnikai eszközök és szolgáltatások értékesítésével foglalkozó vállalkozások sürüsége például kiemelkedö (Rechnitzer 1993). A "fejlett üzleti és személyi szolgáltatások" fogalomkörével nagyjából azonosnak tekinthetö statisztikai foglalkozási kategóriákban - pénzügyi tevékenység, ingatlanügyletek, bérbeadás, egyéb gazdasági tevékenységet segítő szolgáltatás, szálláshely-szolgáltatás és vendéglátás a Budapesten lakó aktív kereső $\mathrm{k}$ részesedése 1996-ban együttvéve mintegy 40\%-os volt, ami - e kategóriákban is csupán a tercier szektor átlagos termelékenységét feltételezve - a GDP-bỏl legalább 65\%-os budapesti arảnyt valószínủsít.

Mindez persze jórészt abból következik, hogy a legdinamikusabb tercier alágazatok területi terjedése egyértelmüen a hierarchikus modellt követi (Rechnitzer 1993). Átfogóan fogalmazva: "a széles tevékenységi kört átfogó szférának itt és most épp azok a szegmensei" "a legdinamikusabbak, amelyek a kialakulási szakaszukban maguk is polarizáló hatásúak (a nagyvárosokhoz kötődnek)"- amelyek pedig "jellemzöen a területi közeledést viszik elöre - pl. az oktatás, egészségügy - épp visszaszorulóban vannak" (Nemes Nagy 1996). A folyamat arányait, differenciáló hatásait nyugat-európai összevetésben is kifejezetten szélsöséges mértékünek kell tekintenünk, hiszen ott sehol nem fordult eló az a jelenség, hogy épp a legmarkánsabb tercierizálódás idổszakában kezdõdjön meg a területi egyenlốtlenségek gyorsuló ütemü növekedése.

A megyék szolgáltató szektorán belül továbbra is a hagyományos ágazatok (közigazgatás, egészségügy, közoktatás, közszolgáltatások, javítás-karbantartás, kereskedelem) dominálnak, amelyek többsége csak kisebb mértékben járul hozzá a helyi gazdaság jelenlegi vagy jövőbeni jövedelemtermelö-képességének fokozásához. Az új vállalkozások pedig - melyek zömmel a tercier szektorban (ezen belül is a kereskedelemben) alakultak - jelentős részben a szük helyi piacot megcélzó, töke- és információszegény kényszervállalkozások. Mindebböl egyenesen következik, hogy vidéken alacsony a tercier gazdaság termelékenysége. A "fejlett szolgáltatásokban" foglalkoztatottak száma jelentősen nött ugyan a megyékben is az 1990-1996. közötti idöszakban - söt, a változás ütemét tekintve a budapesti és a vidéki mutató közel azonos ( 6 év alatt 2,22-szeres, illetve 2,44-szeres a növekedés) - de a korábbi lemaradás, és az alacsonyabb termelékenység miatt gazdasági szerepük még viszonylag csekélynek mondható.

A budapesti gazdaság a szolgáltatások mellett az ipar és a mezögazdaság termelékenységi rangsorát is vezeti, így a gazdaság egészének termelékenységében Budapest mutatója az országos átlag 164\%-a, míg a megyék értékei $67-93 \%$ között szóródnak. E tekintetben a legnagyobb a budapesti és a vidéki gazdaság közötti különbség: súlyozott relatív szórásának értéke Budapesttel együtt $33 \%$, ami a föváros nélkül számítva 10\%-ra csökken. Az a tény pedig, hogy az egy före vetített 
Az ágazati gazdaságszerkezet szerepe a regionális differenciálódásban Magyarországon.

Tér és Társadalom, 12. 1998. 1-2. 138-162. p.

GDP fövárosi adata (178\%) csak kismértékben múlja felül a termelékenység mutatójának értékét (164\%), arra utal, hogy a jórészt gazdaságszerkezeti okokra visszavezethető termelékenységi elönyök sokkal nagyobb szerepet játszanak Budapest dinamikájában, mint - egyébként szintén az országos átlagnál kedvezőbb foglalkoztatási helyzete $\left(2 .{\text { táblázat })^{13}}^{13}\right.$

A termelékenység vidéki adatait vizsgálva a budapesti gazdaságétól valamint a nemzetközileg általánosnak tekinthető modelltől egyaránt jelentősen eltérő ágazati sorrend adódik. Az agrárszektor termelékenysége ugyanis a megyék többségében, és átlagosan, megelözi kissé a másik két ágazatét. E furcsa helyzet oka - az agrárágazat nemzetközi összehasonlításban még mindig viszonylag jó versenyképessége és a másik két szektor, különösen a tercier ágazatok gyenge termelékenysége mellett elsősorban az a tény, hogy a mezőgazdaság GDP-jének megtermelésében más ágazatokhoz képest kimagaslóan nagy a nem-mezögazdasági foglalkoztatottak szerepe (kistermelés, családi gazdaságok stb.), így az ágazat tényleges termelékenysége kisebb a statisztikailag kimutatott értéknél. A mezőgazdaságtól nem sokkal marad el a vidéki ipar termelékenysége (102,9\%), amellyel jelentősen megelözi a szolgáltatásokat $(97,2 \%)$. E jelentös különbséget a tercier szektor elönytelen alágazati összetételéröl korábban elmondottak indokolják, hiszen Budapesttel egyuitt már éppen fordított a jövedelmezőség átlagos sorrendje: a szolgáltatásoké a teljes gazdaságra vonatkozó átlagérték 103,5\%-a, míg az iparé $96,4 \%$, a mezögazdaság mutatója pedig $88,6 \%$.

A regionális politika számára a leglényegesebb kérdés az, hogy az ágazati termelékenységek térségi különbségei hatással vannak-e a területi egyenlőtlenségek alakulására. A korrelációszámítás eredményei szerint érdemi kapcsolat csak az ipar esetében mutatkozik: a $+0,65$ értékủ korrelációs együttható arra utal, hogy termelékenyebb ipar általában a fejlettebb területekre jellemzö. (A legjelentösebb kivétel Borsod-Abaúj-Zemplén, amelynek megmaradt ipara a megyék között a legtermelékenyebb, ám fejlettsége alapján az utolsók közé tartozik.) Az ipar területi súlya mellett tehát az ipari jövedelmezőség is a vidéki gazdaság fejlettségének fontos tényezője, s ennek jelentőségét kiemeli, hogy a három ágazat egyưttes termelékenységének területi differenciáló szerepe $(r=+0,66)$ sem haladja meg lényegesen az iparét. A szolgáltatások esetében a kapcsolat ugyan pozitív elöjelú, de igen gyenge, míg a mezőgazdaság termelékenysége teljesen közömbös a teruleti fejlettség szempontjából.

A területi fejlettségi különbségek ugyanakkor rendre feluulmúlják az élömunkatermelékenység regionális differenciáit, hiszen az egy före vetített GDP megyék közötti relatív szórásához (15\%) képest rendkívül alacsony (mindössze 6\%-os) a termelékenység relatív szórása. Ez arra enged következtetni, a megyék közötti egyenlötlenségeket kevésbé a termelékenységi különbségek, mint inkább foglalkoztatási szerkezet eltérései befolyásolják. Egy logaritmikus mutató segítségével e két tényezö különválasztása és szerepük egzakt mérése is lehetséges. Ezek szerint a vidéki átlagnál fejlettebb, illetve az attól elmaradó megyék 1995-ös fejlettségi kủlönbségei csak 42,6\%-ban származtathatók gazdaságaik eltérö termelékenységéböl, mig 57,4\%-ban a foglalkoztatottsági helyzettel magyarázható a differenciálódás. A reláció a megyék többségében konkrétan is fennáll, hiszen az egy före jutó GDP vidéki átlagától való eltérésüket 19 eset közül 13-ban a foglalkoztatás differenciái magyarázták jobban. 
Az ágazati gazdaságszerkezet szerepe a regionális differenciálódásban Magyarországon. Tér és Társadalom, 12. 1998. 1-2. 138-162. p.

Ez a tény megint csak a magyar piacgazdasági átmenet területi hatásainak sajátos voltára hivja fel a figyelmet, hiszen a "nyugalmi helyzetben" levö gazdaságok esetében szinte törvényszerủ módon a termelékenység szerepe érvényesủl jobban (Nemes Nagy 1987). Várható, hogy a gazdaság "helyreállítási periódusának" lezárultát követően, a tartós növekedés időszakában a megyéket tekintve is megfordul az összefüggés iránya. Egyelöre azonban vidéken elsösorban azon ágazatok fejlödése lehet dinamizáló hatású, amelyek jelentósebb foglalkoztatás-bövitésre képesek. A sikeresnek mutatkozó, modernizálódó vidéki térségekben erre eddig csak a feldolgozóipar volt képes. A mezögazdaságnak hasonlóra, elméleti esélye is alig van. A tercier szektorban pedig, amelyben nemzetközileg - különösen az üzleti szolgáltatásokat tekintve - a leginkább lehetséges a létszámnővekedés, egyelöre a jelenlegi szerkezet termelékenyebbé tétele jelent könnyebben kiaknázható tartalékokat, $\mathrm{s}$ a foglalkoztatás bơvülése csak ezt kővetően válhat a fejlődés tényezőjévé.

\section{A '90-es évek gazdaságszerkezeti változásai és a fejlődés lehetséges irányai}

Az eddigieket összefoglalva akár úgy is fogalmazhatunk, hogy az ipari "jelleg" területi szóródása valamint az ipar differenciáló szerepe egyaránt igen jelentős, a mezőgazdasági "jelleg" szóródása ugyan jelentős, de ennek térségi differenciáló hatása csekély, s ami van, az a területi elmaradottságban mutatható ki. A tercier "jelleg" vidéken igen kis térségi eltéréseket mutat, és a területi egyenlötlenségek kialakításában csak korlátozott jelentősége van. A jövóbeni dinamika lehetőségeinek megitélése szempontjából a legbiztosabb támpontokat ugyanakkor a legutóbbi 1990 óta eltelt - idószak változásainak, azaz a fejlettség helyett a fejlödés ágazati sajátosságainak elemzése nyújtja.

Az 1900. és 1996. évi megyei foglalkoztatási adatok alapján megállapítható, hogy $a$ foglalkoztatás-csökkenés terulleti egyenlőtlenségeinek mértéke nagyjából az egyes ágazatok létszámváltozásának nagyságával állt arányban. A változás szóródását egy, a Hoover-indexszel analóg módszer segitségével mérve a mezỏgazdaság esetében volt a legnagyobb mértékủ a területi arányok változása. Hat év alatt 7,7\%-kal nőtt a mezőgazdasági foglalkoztatásban növekvő szerepü megyék részesedése a keresőkből. A sorban az ipar következik (4,5\%-os arányváltozás), míg a tercier szektor a változásokban is a legkiegyenlítettebb teruleti képet mutatja $(2,7 \%)$. Ezeket az adatokat az egyes ágazatok foglalkozási részesedésével súlyozva kiderül, hogy a megyék gazdasági szerkezetének változásaiban az ipar játszotta a legnagyobb szerepet, de a másik két szektor részesedése is jelentős. Eltérés azonban a statikus vizsgálat eredményeihez képest, hogy Budapesttel együtt számítva csak a szóródás nagyságrendje változik, belső arányai nem: az index értéke az agrárszektor esetében 8,9\%; az iparnál 6,7\%; míg a szolgáltatásokat tekintve 3\%. Mindez arra utal, hogy Budapest gazdasági szerkezetének az országostól való eltérése ma sem jelentösebb mértékü, mint a rendszerváltozáskor volt, azaz a meglévő differenciák alapvetỏen a korábbi időszakok fejlø̋désének hatásait tükrỏzik. $A$ fövảros tercier alapú fejlődése tehát már a 90-es éveket megelôzỏen elkezdődött. 
Az ágazati gazdaságszerkezet szerepe a regionális differenciálódásban Magyarországon.

Tér és Társadalom, 12. 1998. 1-2. 138-162. p.

156 Gyors ténykép

TÉT 1998 1-2

Ezzel ellentétben a megyék fejlettségének egymáshoz viszonyitott, jelenleg mérhetõ egyenlötlenségeiben már sokkal inkább újkeletũ ágazati hatások tükrözödnek, az iparnak a vidék differenciálódásában játszott szerepe pedig kifejezetten "rendszerváltás utáni" fejleménynek tekinthetö. 1990-es területi GDPadatok hiján közvetlen bizonyítékunk ugyan nincsen, ám néhány számítás eredménye erre enged következtetni. Az ipari GDP-termelés 1990-1995 közötti területi változásait az iménti módszerrel megmérve a foglalkoztatásét kétszeresen meghaladó szóródás $(9,6 \%)$ adódott, márpedig az ipari termelésnek a GDP-n belüli részarányát 1995-ben jelentős mértékben meghatározta az elözö öt év termelésnövekedésének éves átlaga $(+0,70)$. Az 1990-1995 közötti ipari termelésnövekedés nagysága magával az 1995-ös GDP-értékkel is elég erösen összefuigg $(+0,65)$, míg az 1990-es egy före jutó ipari GDP-nagyság nem magyarázza az 1995 -ös gazdasági fejlettséget $(+0,16)$.

Az ágazati szerkezet térségi dinamizáló hatásának két összetevője lehet. Az egyik, amikor az adott régió gazdaságában az országosan legdinamikusabb ágazatok részesedése nö a kevésbé dinamikusakéval szemben. Elöfordul azonban olyan eset is, amikor - speciálisan kedvezö helyi adottságokat kihasználva - a régióba települt vállalkozások összességükben jövedelmezöbbek, mint ágazatuk országos átlaga. Az elözỏ esetben az elönyös ágazati struktúra, a másik esetben a lokálisan dinamikus szerkezet előnyét élvezi a terület (Nemes Nagy 1987). E két tényező arányának, szerepének elkülönitése érdekében az 1990. és 1996. évek megyei foglalkozási szerkezeteire vonatkozó adatainkat - mezögazdaság, épitőipar, egyéb iparágak, "hagyományos szolgáltatások", illetve "fejlett uzzleti és személyi szolgáltatások" foglalkoztatottainak száma - az ún. shift-analizis módszerével vizsgáltuk meg ${ }^{16}$. Az eljárás eredményeként minden megyére három elöjeles mennyiségi mutatót kaptunk. Az egyik, a teljes változás, melynek elöjele azt adja meg, hogy az országos átlagnál kisebb (pozitív), vagy nagyobb mértékü (negativ) volt-e a megyében a foglalkoztatás-csökkenés; értéke pedig az országos átlagtól való eltérés nagyságával arányos. A másik két adat a strukturális, illetve a lokális tényezỏ értéke: összegük megegyezik a teljes változással. A strukturális tényezó pozitiv, ha a régióban az országos átlagot meghaladó ütemben nött a foglalkoztatás-bővitő ágazatok aránya (vagy csökkent a munkaerö-leadó szektoroké) - míg a lokális tényezö abban az esetben nagyobb zérusnál, ha az ágazatok összességében dinamikusabbak (kevésbé csökkenó foglalkoztatásúak) voltak, mint az a helyi gazdaságszerkezetböl az országos ágazati átlagok alapján következne. A két tényezö elöjelének összevetése árulja el, hogy a strukturális és lokális sajátosságok egy irányban hatottak-e; abszolút értékeik összevetése révén pedig megtudhatjuk, hogy melyik tényezö szerepe volt a nagyobb a foglalkoztatottsági helyzet változásában.

$\mathrm{Az}$ 5. táblázatból kitünően az elméletileg lehetséges 12-féle kombinációból összesen hat fordult elö. Egyetlen olyan megyénk sincs, ahol mindkét tényezö pozitív lenne, azaz a helyi hatások erösitették volna az országos átlagnál kedvezöbb ágazati szerkezetet. A foglalkoztatás-növelő tercier alágazatok csak Budapesten és Baranya megyében növelték arányukat az átlagot felülmúló mértékben, ami azt mutatja, hogy a tercierizálódás gazdaságot átformáló szerepe döntõen a fóvárosra korlátozódik. A fejlödōképesebb megyék is a tercierizáció ellenében tudtak sikeresen szerepelni, azáltal, hogy az ipar pozitiv lokális hatásának mértéke felülmúlta a strukturális hátrányok nagyságát. Öt megye abszolút értelemben is 
Az ágazati gazdaságszerkezet szerepe a regionális differenciálódásban Magyarországon. Tér és Társadalom, 12. 1998. 1-2. 138-162. p.

vesztesnek tekinthetö (az északkelet-magyarországi térség) esetükben a kedvezőtlen ágazati szerkezet hatását ágazataiknak még az országos átlagoknál is nagyobb mértékben romló foglalkoztatási lehetöségei tovább növelték.

\section{TÁBLÁZAT}

A lokális és strukturális hatások szerepe a megyék foglalkoztatottsági arányainak változásában 1990-1996 között a shift-analizis eredményei alapján (Impact of Local and Structural Factors on Labour Market Trends, 1990-1996) (Results of the Shift Analysis)

\begin{tabular}{|c|c|c|}
\hline & strukturális > lokális & lokális $>$ strukturális \\
\hline $\begin{array}{l}\text { Pozitív strukturális és pozitív } \\
\text { lokális tényező, az átlagosnál } \\
\text { kisebb foglalkoztatás-csökkenés }\end{array}$ & $\ldots$ & $+\cdots$ \\
\hline $\begin{array}{l}\text { Pozitív strukturális és negatív } \\
\text { lokális tényező, az átlagosnál } \\
\text { kisebb foglalkoztatás-csökkenés }\end{array}$ & Budapest & -- \\
\hline $\begin{array}{l}\text { Negativ strukturális és pozitív } \\
\text { lokális tényező, az átlagosnál } \\
\text { kisebbb foglalkoztatás-csökkenés }\end{array}$ & --- & $\begin{array}{l}\text { Bács-Kiskun, Csongrád, } \\
\text { Veszprém, Fejẻr, Zala, } \\
\text { Györ-Moson-Sopron, } \\
\text { Komárom-Esztergom, } \\
\text { Pest, Vas }\end{array}$ \\
\hline $\begin{array}{l}\text { Pozitív strukturális és negatív } \\
\text { lokális tényezö, az átlagosnál } \\
\text { nagyobb foglalkoztatás-csökkenés }\end{array}$ & --- & Baranya \\
\hline $\begin{array}{l}\text { Negatív strukturális és pozitív } \\
\text { lokális tényezö, az átlagosnál } \\
\text { nagyobb foglalkoztatás-csökkenés }\end{array}$ & $\begin{array}{l}\text { Békés, Jász-Nagykun- } \\
\text { Szolnok, Somogy, Tolna }\end{array}$ & C. \\
\hline $\begin{array}{l}\text { Negatív strukturális és negatív } \\
\text { lokális tényezö, az átlagosnál } \\
\text { nagyobb foglalkoztatás-csőkkenés }\end{array}$ & $\begin{array}{l}\text { Szabolcs-Szatmár-Bereg, } \\
\text { Heves, Hajdú-Bihar }\end{array}$ & $\begin{array}{c}\text { Borsod-Abaúj-Zemplén, } \\
\text { Nógrád }\end{array}$ \\
\hline
\end{tabular}

Forrás: saját számitás

$A z$ esetek nagyobb részében - ezen belül valamennyi, relatíve sikeresen fejlödö megyében - a helyi viszonyok szerepe felülmúlta a strukturális tényezök hatását. (A legfejlettebb piacgazdaságokban valamennyi területi egységben a lokális adottságok szerepe nagyobb a területi változásokban.) A romlásért azonban csak a kiterjedt ipari válságtérségekkel rendelkezö megyék (Borsod, Nógrád és Baranya) esetében "felelösek" nagyobb mértékben a helyi tényezök, ami arra utal, hogy a gazdasági visszaesés az ipar differenciáló hatását erösítctte fel legiobban. Az alföldi megvék leszakadása azonban elsösorban strukturális okokra. a tercier szektor kisebb mértékủ növekedésére, valamint a mezõgazdaság kisebb visszaesésére vezethető vissza, ami újólag felhivja a figyelmet a mezögazdaság kevéssé dinamikus jellegére. Mindössze egy esetben - "természetesen" Budapesten - fordult elö, hogy a strukturális hatás a javulásban játszott szerepet.

A megyék közötti mai különbségek kialakulása a Shift-analizis eredményei szerint is az 1990 óta lejátszódott folyamatoknak köszönhetóo ${ }^{17}$. A Budapest és Pest megye nélkül számított rangkorrelóció az 1995-ös gazdasági fejlettség és az 1990-1996. közötti foglalkoztatottság-változás mértéke között $+0,91$ értékü, ami bizonyítja egyrészt az 1990 óta eltelt időszak, másrészt a foglalkoztatás - és az ennek 
Az ágazati gazdaságszerkezet szerepe a regionális differenciálódásban Magyarországon.

Tér és Társadalom, 12. 1998. 1-2. 138-162. p.

változásaiban központi szerepet játszó ipar - kiemelkedö szerepét a vidéki Magyarország megyéi közőtt jelenleg létezỏ fejlettségi differenciák kialakításában.

A folyamatok ilyen irányú alakulásában a magyar iparba áramló külföldi müködôtókének, ezen belül kiemelten a multinacionális nagyvállalatoknak kell meghatározó szerepet tulajdonitanunk, az oly sokat emlegetett közép- és kisvállalkozásoknak egyelöre nincs kimutatható hatása a területi fejlettségi különbségek alakulására. Annak ellenére, hogy az "ötlet" és a minőségi termelés zömmel a magteruleten marad, ez az új régióközi, illetve nemzetközi munkamegosztás ${ }^{18}$ (Benko 1997) meghatározó szerepet játszik az egyes régiókban megindult ipari modernizációs folyamat, illetve az ezen alapuló terulleti fejlödés eddigi sikereiben is. Ezt igazolja, hogy Magyarországon ma a feldolgozóipar az az ágazat, amelyben a legnagyobb mértékũ a külföldi tõke jelenléte. Míg 1995-ben a gazdaság egészét tekintve a hozzáadott értéknek csak 14,2\%-a származott külföldi tulajdonú vállalkozásokból, addig a feldolgozóiparban $32,7 \%$-os ez az arány. ${ }^{19}$ Fordított nézőpontból ugyanezt fejezi ki, hogy a külföldi tókebefektetések ágazati megoszlását tekintve meghatározó az ipar szerepe: az 1996-ig hazánkba érkezett külföldi tóke 48,5\%-a a feldolgozóiparba áramlott (Diczházi 1997). Általánosan elfogadott az az álláspont, hogy az ország 1995-től meginduló gazdasági dinamikáját is elsősorban az iparnak kőszőnheti, márpedig az elmúlt évek ipari termelésnövekedése mértékadó becslés szerint közel 80\%-ban a zöldmezös külföldi befektetéseknek volt köszönhetö (Diczházi 1997).

Meggyözö bizonyítékot szolgáltat az ipari alapú gazdasági dinamika, illetve az ipar regionális differenciáló szerepének igazolására a nemzetkőzi tỏkebefektetések területi megoszlásának vizsgálata. Már a '90-es évtized elején a föváros környéki és egyes dunántúli térségekben található települések, illetve gazdasági egységek biztosították a legmegfelelöbb feltételeket a kullfóldi vállalkozások megtelepedéséhez (Rechnitzer 1993). A gazdasági tevékenység helye szerint számbavéve a befektetéseket kiderull, hogy 1996 végéig Budapestre és Pest megyébe áramlott a Magyarországra érkezett külföldi töke 46\%-a, 26\%-a pedig az iparfejlödésben élenjáró Vas, Györ-Moson-Sopron, Fejér, Komárom-Esztergom és Veszprém megyékbe került. E tơkék nagyon eltérö ágazati megoszlása közvetlen kapcsolatban van a korábban felvázolt sajátos gazdaságfejlödési irányokkal. A budapesti agglomeráció részesedése $80-90 \%$-ot is elér a pénzügyi szektor, a raktározás-logisztika, illetve az irodaház-beruházások terén, a külföldi tulajdonú bankok, biztositók, brókerházak pedig valamennyien a fôvárosba telepítették központjaikat. Ezzel ellentétben a felsorolt öt dunántúli megyébe került az országban 1996-ig megvalósult zöldmezős ipari beruházások 70\%-a. Az ország összes ilyen jellegủ tókeberuházásának kb. felét adó hét multinacionális cég General Motors, Audi, Suzuki, IBM, Ford, Philips, Guardin Glass - tevékenysége szinte kizárólag a Dunántúlra korlátozódik (Diczházi 1997), márpedig a tơbbi tőkebefektetési formával osszehasonlitva leginkább a zöldmezős beruházások járulnak hozzá (kőzvetlen és közvetett hatásaik révén) a területi gazdasági fejlödéshez. Kutatásunk eredményei tükrében e hatások kð̋zül az általuk teremtett mintegy 50 ezer új ipari - döntően gépjármüipari illetve elektronikai, kisebb részben vegyipari, csomagolástechnikai és speciális élelmiszer-gyártási munkahely szerepét kell a legfontosabbnak tekintenünk. ${ }^{20}$ 
$\mathrm{Az}$ ipari fejlődési modell jövôbeni lehetőségeinek megítéléséhez két problémát kell tisztázni. Az egyik: mennyire tekinthetö megalapozottnak, azaz tartós lehet-e a jelenlegi növekedés - míg a másik, részben az elözővel összefüggő kérdés: az eddigieken túl újabb területeken is megindulhat-e az ipari alapú dinamika, illetve megteremthetōk-e ennek feltételei?

$\mathrm{Az}$ elsỏ kérdéssel kapcsolatban az egyoldalúan csak az iparra alapozott fejlödésben rejlö bizonytalansági tényezőkre kell felhívni a figyelmet. Ez a modell ugyanis kétszeres értelemben is függõ jellegũ: konjunkturális hatósoknak és a külföldi tőkeérdekek változásainak egyaránt ki van téve, hiszen a "multik" gyakran csak a közvetlen termelést telepítették át Magyarországra, így azt adott esetben könnyen fel is számolhatják, vagy áthelyezhetik a nálunk kedvezöbb feltételeket kínáló országokba. Ez annál is inkább bekövetkezhet, mivel üzemeik többnyire nem a magyar piacra, hanem a kelet-európai régió igényeinek kielégitésére, leginkább pedig az EU-országok vásárlói számára termelnek. A sikeres dunántúli ipari régiók stratégiájának legfontosabb fogyatékossága éppen az, hogy nem számol az ebból eredö veszélyekkel, ${ }^{21}$ igy modelljük legfeljebb középtóvúnak nevezhetö.

A túlságosan egyoldalú ipari alapú fejlödés mindemellett strukturális jellegü problémákat is felvet. Több külföldi példa utal arra ugyanis, hogy a fejlettebb területek "szû́rỏjéből" kihullott hagyományos gazdasági ágak betelepülése a periférikus régiókba csak átmeneti eredményeket hoz, ugyanakkor hosszú tóvon a gazdasági szerkezet konzerválása miatt általában nem eredményes stratégia (Horváth 1994). Ez a veszély az egyelöre sikeresnek tủnő "ipari térségek" esetében is fennáll, hiszen dinamikájuk egyértelmủen a termelésre alapozódik, $\mathrm{s}$ a töke, a piac, illetve az innováció jellemzően külsỏ hatásként jelenik meg. $A$ "szürö" ráadásul kettôs: a külföldi "multik" az ipari, mig Budapest a tercier fejlödés lehetôségeinek határait szabják meg, ezért még a sikeres régiók országon belüli periféria-jellege sem csökken, hanem új elemekkel egészül ki. Az ipari alapon fejlödỏ térségek további sorsa szempontjából ezért létkérdés a belföldi termelési kooperációk hálózatának erősítése, a kapcsolódó gazdasági szolgáltatások körének folyamatos bővitése, a körzeten belüli horizontális integráció (Benko 1997) erösitése, összefoglalóan: fugggö helyzetük oldása és továbbfejlődésük belső alapjainak megteremtése. $\mathrm{Az}$ újonnan iparosodó régiók ilyesfajta fokozatos átalakulására számos amerikai és nyugat-európai példa hozható: a betelepult ipar externális hatásai révén - egy idö után már elsősorban a tercier szektor bőviluésére van hatással. ${ }^{22}$

A második problémát tekintve azt kell megállapítani, hogy az ipari alapú területi fejlődés jelenlegi modellje valószínúleg a vidéki régiók közötti regionális differenciálódás további növekedésével fog járni addig, amíg "a gazdaságban a fejlett piacgazdaságokra jellemzỏ reálarányok helyre nem állnak, azaz a termelöágazatok helyét a tercier és kvaterner szektorok veszik át" (Nemes Nagy 1996). Kevés esély mutatkozik ugyanis arra, hogy a jelenlegi modell alapján az ország más nagyobb térségeiben is ipari alapú fejlödés induljon. ${ }^{23} \mathrm{~A}$ külföldi ipari tőke megjelenésének felsorolt objektiv feltételei kevés, az ipari dinamikától még "érintetlen" régióban léteznek, vagy teremthetök meg gyorsan és gazdaságosan. A jelek szerint a "multik" szándékai is ellentétesek ezzel: számos megvalósult zöldmezős beruházásnál ugyanis a szükségesnél jóval nagyobb területet vásároltak meg, s ma igyekeznek idetelepiteni külföldi beszállitóikat. Az új befektetök is a már 
"bevált" területeket keresik annak ellenére, hogy esetenként nincs már elegendö szabad munkaeró, s ilyenkor a szomszédos falvakból, de akár nagyobb távolságból is vállalják a dolgozók beutaztatását (Diczházi 1997). Ezért még az arra legalkalmasabb térségek nagyobb részének sincs sok esélye az ipari alapú felzárkózás modelljének adaptálására, bár közepes nagyságú külfơldi és hazai vállalkozások, elsósorban beszállítók megtelepedésére tőbb helyen is kedvezó lehetőség kínálkozik, s így az ipar szerepet kaphat a helyi gazdaság megerősödésében. ${ }^{24}$

E megfontolások alapján az a következtetés adódik, hogy - a jelenlegi tendenciák ellenére - a periféria felzárkózásának, $s$ ennek révén a területi különbségek kiegyenlítődésének alapja hosszú távon a tercier szektor fejlödése lehet (Horváth 1994). Ebben az ágazatban képzelhetö el jelentősebb mértékủ és hatékony foglalkoztatás-bövités, ami a belső kereslet növekedéséhez, a helyi cégek versenyképességének erösítéséhez és a régiók exportjának növeléséhez is hozzájárulhat (Raffay 1997). Vizsgálataink azonban azt mutatták, hogy a vidéki gazdaság leggyengébb "láncszeme" a szolgáltatások kedvezőtlen belsỏ szerkezete, alacsony termelékenysége. Ebből következöen a régiók többségében a tercier szektor termelékenyebbé tétele a területi fejlödés legföbb feltétele. Ugyanakkor az ehhez szükséges feltételek megteremtése: a helyi lakosság képzettségének emelése a regionális gazdasági stratégiákhoz illeszkedö módon; a régiók közötti kommunikáció feltételeinek javitása; ${ }^{25}$ az egységesen magas szinvonalú közlekedési hálózatok kiépitése stb. azok a problémák, amelyek felszámolására a ma kevésbé sikeres régiók zöme önerejéböl képtelen, megoldásuk ennélfogva az országos regionális politika feladatát kell, hogy képezze.

\section{Jegyzetek}

${ }^{1}$ A tanulmány alapjául szolgáló vizsgálatok a MTA Stratégiai Kutatások "Teruletfejlesztési Nemzeti Program megalapozása: a regionális- és településfejlődés folyamatai Magyarországon" c. témája keretében folytak 1997-ben.

${ }^{2}$ Ezt azzal egyutt is figyelembe kell venni, hogy ellentétes irányú - externalizációs - folyamatok is megfigyelhető́k: a multinacionális konszernek egy része számos speciális funkciójú egységet onálló gazdasági társasággá alakit, azaz formailag is leválaszt saját szervezetéröl.

${ }^{3} \mathrm{Az}$ osszefuggés kózgazdasági hátterét egyebek kozơt az adja, hogy a másik két szektortól eltérỏen a mezőgazdaság - termelési tényezőinek a természeti feltételektől való erős fúggősége miatt - egy bizonyos határon túl csak rendkívül kóltségesen, vagy egyáltalán nem képes novelni termékkibocsátását, kínálatát. Az élelmiszerek iránti kereslet mennyiségi oldalának pedig fiziológiai korlátai vannak, azaz a piacbővités lehetőségei is behatároltak: új szükségletek keltése csak egy másik szukséglet rovására tơrténhet.

${ }^{4}$ A kőolajbányászatáról ismert holland Groningen tartomány ipari GDP-jének részesedése haladta meg kissé az 50\%-ot.

3 A módszer pontos leírását és számos alkalmazását is tartalmazza Nemes Nagy József munkája (Nemes Nagy 1987). Hasonló és gyakrabban használt ún. egydimenziós koncentrációs mutató a súlyozott relativ szórás is, amelynek egyes, az 1995-1996-os gazdaságszerkezeti egyenlötlenségekre vonatkozó értékeit a 2. táblázatban közolljük. Ez az eljárás lényegileg ugyanazokra a kovetkeztetésekre vezetett, amelyeket a kovetkező bekezdésekben fogalmazunk meg.

6 Ebbe belejátszik ugyanakkor a GDP-becslés módszere is: a koncentráltan keletkezó tercier jovedelmeket ugyanis általában a - meglehetösen homogén teruleti struktúrájú - bérek, illetve foglalkoztatotti létszám arányában osztja meg a megyék kozzott a KSH.

${ }^{7}$ A volumenindexek értékeit Nemes Nagy József gyüjtotte ossze (Nemes Nagy 1997).

${ }^{8}$ Ez a munka, valamint egy másik hasonló becslés (Agócs-Tábi 1982) lehetöséget adott arra is, hogy az 1995-ðs ipari GDP-böl visszavezetett ipari jovedelem-értékek megbizhatóságát ellenörizzuk 1965-re, 
illetve 1980-ra vonatkozóan. Mivel az alltalunk kiszámított, illetve a korábbi becslésekben szereplö adatok kozơtti korreláció igen magas $(+0,995$, illetve $+0,978)$ volt, az eljárás használhatóságához nem férhet kétség.

${ }^{9}$ N. Vanhove és L.H. Klaassen adatait Nemes Nagy József munkája ismerteti (Nemes Nagy 1987).

${ }^{10}$ A szigeteket, valamint a volt NDK-s tartományokat - speciális helyzetuk miatt - kihagytuk a számitásokból.

" Az adatok értékelésénél figyelembe kell venni, hogy minél kevesebb a vizsgált teruleti egységek száma, annál nagyobb hatása van a korrelációs együttható alakulására egy-egy, az átlagostól jelentősen eltérỏ gazdaságszerkezetủ régiónak. Ez utóbbiak kozul a legfontosabbak az egyetlen sürün lakott agglomerációból álló, nagyvárosi szerepkơuukböl adódóan is túlnyomórészt tercier jellegü térségek, amelyek eltéritö hatása kulơnosen a túlsúlyos fövárosi régióval rendelkezö kis országok esetében jelentős.

12 Érdekes osszefüggés az is, hogy mikozzben a tercier szektor GDP-részesedése kozzepes negatív korrelációban van a gazdasági fejlettséggel $(r=-0,50)$, addig a tercier GDP relatív nagysága pozitívan korrelál az egy före jutó GDP értékével $(r=+0,77)$. Ez az ellentmondás azonban csak látszólagos. Egyrészt a tercier szektor nagyobb gazdasági súlya inkább azon fejletlen megyékre jellemzó, ahol az iparosodottság alacsony fokú és esetleg a mezógazdaság sem kưlonősebben fejlett. Másrészt a tercier szektor gazdasági súlyának megyék kozzotti szóródása igen csekély mértékü - így a nagyobb GDP-jü megyékben a szolgáltatások viszonylag kisebb GDP-n beluli aránya mellett is nagyobb volumenú tercier jovedelem képződik. Megállapitásunkat igazolja, hogy az egy före jutó tercier GDP nagysága korrelálatlan az ágazatnak a megyei GDP-n belali részesedésével $(r=+0,16)$, míg a másik két szektor esetében igen erōs a kapcsolat (mezógazdaság: $r=+0,89$; ipar: $r=+0,88$ ).

${ }^{13}$ A tisztánlátás érdekében azonban mindenképpen meg kell jegyezni, hogy a budapesti termelékenységi adatok esetében kulonősen nagy a statisztikai adatfelvétel sajátosságaiból eredö torzítás. A KSH felmérései során ugyanis az agglomeráció telepuléseiböl Budapestre bejáró - Pest megyej foglalkoztatottként nyilvántartott - dolgozók által termelt GDP Budapestnél jelenik meg, míg Pest megye GDP-jéből ez a jovvedelemtömeg hiányzik - így a két teruletre kozőlt adatok kulon-kuloon nehezen, inkább csak összevontan értelmezhetők. Az egy foglalkoztatottra jutó GDP-t megadó termelékenységi mutató esetében még nagyobb mértékú a torzitás. (Ez - az adatok tanúsága szerint kưlönősen a tercier szektor esetében jelentős, hiszen semmilyen más indokkal nem magyarázható Pest megyênek még a tobbi megyétól is jelentősen elmaradó termelékenységi mutatója - ami arra enged kővetkeztetni, hogy az agglomerációból beingázó munkavállalók zóme tercier keresó).

${ }^{14}$ A számitási eljárást részletesen ismerteti Nemes Nagy József munkája (Nemes Nagy 1987).

${ }^{15} \mathrm{Az}$ 1990-es megyei ipari GDP-értékeket itt is az 1995-ös adatnak a KSH által közölt volumenindexek alapján tơténö visszaszámításával becsultúk.

16 A shift-analizis (="változás-elemzés") részletesebb matematikai leírása tobob munkában is megtalálható (lásd pld. Sikos T. Tamás szerk. Matematikai és statisztikai módszerek alkalmazási lehetőségei a terujeti kutatásokban. Bp. 1984).

171990 elö́t az ipari termelés alakulása - a hatékonyság szempontját figyelmen kivuul hagyó, felulről irányított jovedelem-újraelosztás miatt - megyénként nagyjából egységes volt, s az iparfejlödési ưtem sem mutatott érdemi kapcsolatot a teruletỉ fejlettség szinvonalával (Nemes Nagy 1997).

${ }^{18} \mathrm{Az}$ ilyen típusú munkamegosztás, amely - bár a termelés fôldrajzi szétterjedésével jár - alapvetỏen egyetłen multinacionális vállalat integrációja alatt zajlik, még tipikusan fordista jelenség. A posztfordista ipari kőrzetek létrejôtte a termelöfolyamat egy-egy kisebb szegmensére specializálódó, egymáshoz folldrajzilag kơzel lévő, de egymástól fưggetlen kisebb cégek kőzőtt létrejovő munkamegosztáson alapul (Benko 1997).

${ }^{19}$ Összehasonlitásképpen: a mezögazdaságban csak $1,4 \%$, a személyi szolgáltatásokban kb. 1-4\%, míg az uzleti szolgáltatásokban $\mathrm{kb}$. 15-20\%-os volt a külfoldi tulajdonú vállalkozások által termelt hozzáadott érték részesedése 1995-ben a Magyar Statisztikai Zsebkönyv adatai szerint.

${ }^{20}$ A magyar teruleti fejlödés külonös paradoxona, hogy - bár a tökebefektetések kózel fele a központi régióba áramlott - mégis a vidéki sikeres térségek kerultek inkább a külfơldi tỏke "uralma" alá. Az utóbbi esetben ugyanis épp a legdinamikusabb ágazatban meghatározó a kulfơldi jelenlét, míg a föváros leggyorsabban nővekedő szektorában egyelöre (1996-ig) viszonylag kisebb a külfóldi tulajdonosok szerepe.

${ }^{21}$ Ezt bizonyitja például, hogy az egyébként igazán sikeresnek mondható Székesfehérvár legnagyobb ipari parkjában az 1995-0s árbevétel $95 \%$-a bérmunka-jellegü tevékenységekböl származott (Lốrincz 1996). 
${ }^{22}$ A sikeresen fejlödŏ ipari jellegŭ régiók másik - az országban szétszórtan található - csoportjában viszont, amelyek stabilitásukat egy-egy stratégiai jelentőségủ magyar nagyvállalatnak kőszonhetik (Százhalombatta, Tiszaújváros, Paks, Martfü, Dunaújváros térsége) a vállalkozási aktivitás erősitése és a regionális gazdaság diverzifikálása a legföbb feladat.

${ }^{23}$ Az ipari tóke betelepedése egyébként nem igazából regionális jellegü. A dinamikus iparvállalatok nem bizonyos térségekben szétszóródva, hanem egy-egy nagyobb centrumban koncentrálódva, szigetszerúen jelennek meg, s nơvelik meg régiójuk iparának mérőszámait - mikőzben a kơzponttól távolodva még foglalkoztatási hatásuk is hamar minimálisra csokken (ĺgy pld. Szentgotthárd adja a Vas megyei ipari produkció közel felét, Fejér megye iparosodottsága dőntóen Székesfehérvárnak és Dunaủjvárosnak kőszönhető. Vỉszonylag szórtabb ipartelepưlésrớl csak Györ-Moson-Sopron megyéböl vannak ismereteink). Az ipari alapú fejlödés további sikerének egyik alapfeltétele a szélesebb regionális integrácio kialakítása, a centrumoktól távolabbi teruletek kapcsolódásának megszervezése - beingázás, kis- és középvállalkozásokból álló beszállitói hálózat kialakitása, a gazdasághoz kapcsolódó tercier funkciók egy részének vidékre telepítése stb. - lehet.

${ }^{24} \mathrm{Az}$ utóbbi hónapokban ugyanakkor néhány halvány jel arra utal, hogy a külfơldi ipari tőke mégiscsak átlépi talán a Duna vonalát. Ezek kózé tartozik - az eddigi ipari területek némelyikén mutatkozó munkaerőhiány kényszerító ereje mellett -, hogy a fỏváros kőzelsége és jó megkőzelíthetősége megfelelö telephelyet kínál a nagyobb részben a magyar piacot megcélzó vállalatok számára (Godollö, Kecskemét), mig más esetekben - a regionális politika által is támogatottan - a hatalmas keleti piacok megnyilásának ígérete jelent vonzerởt (Nyíregyháza, Záhony). E tényezök külơnosen fontossá válhatnak abban az esetben, ha a világgazdaság más, jelentős tőkebefektetéseket vonzó régiói (elsősorban Délkelet-Ázsia) gazdaságainak megrendülése miatt felértékelödnek a kőzép-kelet-európai országokba irányuló tơkekivitel lehetöségei.

25 Kulonosen fontos ezen belül a Budapesttel osszeköttetést teremtő nem-hierarchikus jellegü kapcsolatok erösitése: csak így van esély arra, hogy az európai nagyvárosi fejlődési utat járó fóváros szolgáltató szektorának dinamikájából a távolabbi térségek is profitálhassanak, s ne a centrum fôlényének további erősodése kơvetkezzen be.

\section{Irodalom}

1990. évi népszámlálás. Megyei kotetek. KSH, Bp. 1991, 1992.

Agócs Mihályné-Tábi Ferenc (1982) Az ipari termelés változásának megyei szintủ mérése. Területi Statisztika 1-2.1-7.0.

Barta Györgyi (1977) A területi gazdasági kưlónbségek változása 1960 és 1975 közoutt. Területi Statisztika 5. 522-537. o.

Benko, Georges (1997) A regionális fejlödés útjai: globálistól a lokálisig. Tér és Társadalom 2. 1-16. o. A bruttó hazai termék (GDP) terilleti megoszlása 1995-ben. Kézirat. KSH Sajtóosztálya, Bp. 1997.

Diczházi Bertalan (1997): Kulfờldi tőkebefektetések hatása a regionális gazdaságra. Tér és Társadalom 2. 67-79. 0 .

Enyedi György (1996) Regionális folyamatok Magyarországon. Hilscher Rezsö Szociálpolitikai Egyesület, Bp. 138. o.

Enyedi Gyorgy (1997) A területfejlesztési politika dilemmái. Kritika 7. 12-15. o.

Horváth Gyula (1994) A Dél-Dunántúl nemzetkozi versenyképességének elófeltétele, a technológiai megújulás. Tér és Tărsadalom 1-2. 37-58. o.

Kovács Teréz (1997) A vidékfejlesztés problémái és feladatai. A falu 2. 11-17. o.

Lörincz Sándor (1996) Iparfejlesztési eredmények Székesfehérváron. Ipari Szemle 4. 43-45. o.

Mikrocenzus (1996) A népesség és a lakások jellemzbi. KSH, Bp. 1997.

Nemes Nagy József (1987) A regionális gazdasági fejlódés összehasonlitó vizsgálata. Akadémiai Kiadó, Bp. 218. o.

Nemes Nagy József (I996) Centrumok és perifériák a piacgazdasági átmenetben. Fóldrajzi Közlemények 1.31-48. 0.

Nemes Nagy József (1997) Radikális változások a magyar ipar térszerkezetében. Elöadás a Magyar Fold drajzi Társaság jubileumi konferenciáján. Kézirat. 28. 0.

Raffay Zoltán (1997) A szolgáltatások és a regionális fejlödés. Comitatus 6. 5-12. o.

Rechnitzer János (1993) Szétszakadás vagy felzárkózás. MTA Regionális Kutatások Központja, Györ, 208. 0.

Regions. Statistical Yearbook (1995). EUROSTAT, Luxembourg 1996 